\title{
Cumhuriyetten Günümüze Sosyal Bilgiler Programlarının Sosyal Bilgiler Öğretim Yaklaşımlarına Göre İncelenmesi*
}

\section{An Investigation into the Social Studies Programs from the Early Republic to the Present in terms of Social Studies Teaching Approaches}

\author{
Ali YALÇIN** (iD) Nadire Emel AKHAN ${ }^{* * *}$ (iD)
}

Received: 11 April 2018

Research Article

Accepted: 09 May 2019

\begin{abstract}
The aim of this study is to examine social studies programs in terms of social studies teaching programs from the foundation of the Turkish Republic in 1923 to the present day. The historical method - a survey model used in qualitative research methods - was employed in the study. The data obtained from literature review were analyzed with regards to social studies teaching approaches based on descriptive analysis. The findings showed that issues regarding the citizenship transmission which belong to social studies approaches were definitely included more or less within primary school social studies programs of 1924, 1930, 1948, 1961, 1968, 1990 and secondary school social studies programs of 1932, 1938, 1949, 1962, 1970, 1985. Moreover, topics related to the disciplines of social studies (history, geography, law, politics, economy, sociology) were also identified within these programs. Findings regarding the characteristics of the reflective research approach were not reached in the secondary school programs of 1932, 1938. On the other hand, it was found out that the issues regarding the 3 approaches of social studies (social studies as the citizenship transmission, social studies as social sciences and social studies as reflective inquiry) were included in 1968, 1990, 1998, 2005, and 2017 programs.
\end{abstract}

Keywords: social studies teaching approaches, social studies programs, primary school programs, secondary school programs, elementary school programs.

ÖZ: $\mathrm{Bu}$ çalışmanın amacı, cumhuriyetten günümüze sosyal bilgiler programlarının sosyal bilgiler öğretim yaklaşımlarına göre incelenmesidir. Araştırmada nitel araştırma türlerinden tarama modeli içinde yer alan tarihsel yöntem kullanılmıştır. Çalışmada, literatür taraması sonucunda elde edilen veriler sosyal bilgiler öğretim yaklaşımları açısından betimsel analiz tekniğine dayalı olarak analiz edilmiştir. Araştırmanın bulgularını genel olarak değerlendirdiğimizde; 1924, 1930, 1948, 1961, 1968, 1990 ilkokul programları ile 1932, 1938, 1949, 1962, 1970, 1985 tarihli ortaokul programları sosyal bilgiler öğretim yaklaşımlarından vatandaşlık aktarımına ait özelliklere mutlaka yer verildiği görülmüştür. Ayrıca bu programlarda sosyal bilimlerin disiplinlerine (tarih, coğrafya, hukuk, siyaset bilimi, ekonomi ve sosyoloji) ait konular da tespit edilmiştir. 1932 ve 1938 ortaokul programlarında, yansıtıcı araştırma yaklaşımının özelliklerine uygun bulgulara ulaşılamamıştır. 1968, 1990, 1998, 2005 ve 2017 programlarında ise diğer programlara göre daha belirgin olarak sosyal bilgilerin üç yaklaşımına (vatandaşlık aktarımı olarak sosyal bilgiler, sosyal bilimler olarak sosyal bilgiler ve yansıtıcı araştırma olarak sosyal bilgiler) ait özelliklere yer verildiği tespit edilmiştir.

Anahtar Kelimeler: sosyal bilgiler öğretim yaklaşımları, sosyal bilgiler programları, ilkokul programları, ortaokul programları, ilköğretim programları.

\footnotetext{
* It was produced from the first author's master thesis.

** Corresponding Author: $\mathrm{PhD}$ student, Uludăg University, Bursa, Turkey, aliylcnn77@gmail.com, https://orcid.org/0000-0001-8421-3924

*** Assoc. Prof. Dr., Akdeniz University, Antalya, Turkey, neakhan@akdeniz.edu.tr, https://orcid.org/0000-00033628-8571
}

\section{Citation Information}

Yalçın, A., \& Akhan, N. E. (2019). Cumhuriyetten günümüze sosyal bilgiler programlarının sosyal bilgiler öğretim yaklaşımlarına göre incelenmesi. Kuramsal Eğitimbilim Dergisi [Journal of Theoretical Educational Science], 12(3), 842-873. 


\section{Giriş}

Sosyal Bilgiler, iyi-etkin insan yetiştirmeyi hedefleyen ilkokul ve ortaokul dönemi öğrencilerini toplum hayatına hazırlayan temel bir derstir. $\mathrm{Bu}$ dersin öğretmenleri mevcut programdan yola çıkarak öğrencileri gerçek hayattan kesitlerle buluşturarak onları toplumun "iyi-etkin" birer yurttaşı yapmaya çalışırlar. Cumhuriyetten günümüze programlara baktığımızda her dönemin kendi ihtiyaçları doğrultusundan iyi-etkin vatandaşı şekillendirdiği görülmektedir. $\mathrm{Bu}$ hedefi gerçekleştirirken de programın ve uygulayıcısı konumundaki öğretmenler için sosyal bilgiler öğretim yaklaşımları önem kazanmaktadır.

Bilimsel ve teknolojik alanda kaydedilen hızlı gelişmeler, bireyin geçmiş yıllara göre daha karmaşık problemlerle karşılaşmasına neden olmaktadır. Bunların çözümü için birden çok disiplinin bulgularından yararlanılması ve disiplinler arası anlayışın benimsenmesi gerekmektedir. Bu noktada içinde yaşadığımız toplumu daha iyi anlamak, toplumun iyi bir vatandaşı olabilmek ve toplumda yaşanan değişimlere ayak uydurabilmek için sosyal bilimleri daha iyi anlamak oldukça önemlidir (Akhan \& Şimşek, 2015; Bilgili, 2006).

Bilindiği gibi sosyal bilimler, insan davranışlarını çeşitli yönlerden, nesnel bir yaklaşımla inceleyen alanlardan meydana gelmektedir. Bu bağlamda sosyal bilimler, insanın insanla ve çevresiyle etkileşiminden doğan bilgilerle insanı ve toplumsal yönlerini kanıtlamak amaciyla oluşan bilimler topluluğudur (Barth \& Demirtaş, 1997; Tay, 2013). Sosyal bilgiler ise vatandaşlık yeterlilikleri kazandırmak için sanat, edebiyat ve sosyal bilimleri disiplinler arası bir yaklaşımla birleştirerek meydana gelen bir çalışma alanıdır (NCSS, 1993). Sosyal bilgiler, sosyal bilim dallarından gelen içeriği kullanarak çeşitli konularla ilgili gelecekte vatandaşların sosyal konular hakkında daha iyi düşünerek seçimler yapmalarına yardımcı olmaktadır (Savage, 1996).

Ülkemizde sosyal bilgiler programlarının kapsamına giren dersler, ilk kez Sultan II. Abdülhamid (1876-1909) zamanında ilkokul programlarında yer aldığ1 belirtilmektedir. Bu dönemde yalnız tarih ve coğrafya dersleri programlarda yer almıștır (Öztürk \& Otluoğlu, 2002). Cumhuriyet döneminde ise 1924 programında yer alan Musahabat-ı Ahlakiye ve Malumatı Vataniye dersi, 1926'da Yurt Bilgisi dersi olarak değiştirilmiştir. 1926 İlkokul Programı, zamanla yapılan değişikliklerle 1962 yılına kadar geldiği söylenebilir. 1962'de disiplinler arası bir yaklaşımla "Toplum ve Ülke Incelemeleri” adı altında birleştirilmiştir. 1968 yılında yapılan değişiklikle ilkokulun 4. ve 5. sınıflarında "Sosyal Bilgiler" adı altında bir bütün haline getirilmiştir. 1985'te ortaokullarda sosyal bilgiler dersi kaldırılarak yerine milli tarih, milli coğrafya ve vatandaşlık bilgileri dersleri konulmuştur. Daha sonra 1992'de yeni bir vatandaşlık bilgileri programı uygulamaya konulmuştur. 1997'de sekiz yıllık zorunlu eğitim sonucunda milli tarih ve milli coğrafya dersleri kaldırılarak 1998'de yerine 4-7. sınıfları kapsayacak şekilde yeni bir sosyal bilgiler dersi öğretim programı yürürlüğe konulmuştur. Özellikle dünyadaki bilimsel ve teknolojik gelişmelerin Türkiye'ye yansımaları, eğitim biliminde yeni gelişmeler, ekonomiye ve demokrasiye duyarlı bir eğitim ihtiyacı gibi gelişmeler yeni bir program hazırlığına girmesine neden olmuştur. Bunun sonucunda, 2005 yılında yeni sosyal bilgiler dersi öğretim programı oluşturulmuştur. $\mathrm{Bu}$ programın en önemli özelliği, eski programın davranışçı anlayışından vazgeçilerek yapılandırmacı anlayışta öğrenme ilkesini benimsemesidir (Bilgili, 2006). 
Bilim ve teknolojide yaşanan hızlı değişim, bireyin ve toplumun değişen ihtiyaçları, öğrenme öğretme teori ve yaklaşımlarındaki yenilik ve gelişmeler yetiştirilmesi hedeflenen nitelikli insandan beklentileri arttırmış ve 2005 Sosyal Bilgiler Programı tekrar düzenlenerek 2017 y1lında 5. sinıflarda pilot okullarda, 2018-2019 eğitim öğretim döneminde tüm okullarda uygulamaya koyulmuştur. Güncellenen sosyal bilgiler programı ile bireylerin yetişmesine hizmet edecek öğretim programları salt bilgi aktaran bir yapıdan ziyade bireysel farklılıkları dikkate alan, değer ve beceri kazandırma hedefli, sade ve anlaşılır bir yapıda hazırlanmıştır (Milli Eğitim Bakanlığı [MEB], 2018).

Tarihi süreçte eğitim felsefesi alanında çalışan uzmanların, farklı görüşleri olduğu gibi sosyal bilgiler alanında çalışan eğitim uzmanlarının da sosyal bilgilerin aktarımı hakkında farklı fikirler ortaya koyduğu görülmüştür (Doğanay, 2005). 1950'lerden itibaren sosyal bilgiler öğretim yaklaşımlarında, tutarlı bir amaçtan ve hedef dizisinden yoksun olduğu görülmüştür. Böyle bir durumun eksikliği sonucunda öğretmenler, en iyi içeriğe ve en uygun yönteme karar verememekteydiler (Barr, Barth, \& Shermis, 1978). Bunun için sosyal bilgiler eğitimiyle ilgilenen bilim insanları, çeşitli çalışmalar yürüterek sosyal bilgilerin doğasını oluşturan öğretim yaklaşımlarını tespit etme arayışı içerisine girmişlerdir. Bu çalışmalardan birini yürüten Barth ve Shermis, 1970 yılında yazdıkları bir makalede sosyal bilgiler öğretim yaklaşımlarına ilişkin bir sınıflama yapmış, bu sınıflama daha sonra Barr, Barth ve Shermis (1977) tarafindan yayınlanan "Defining The Social Studies (Sosyal Bilgileri Tanımlamak)" adl1 çalışmalarında üç yaklaşımı belirtmişlerdir (Akt. Öztürk, 2006).

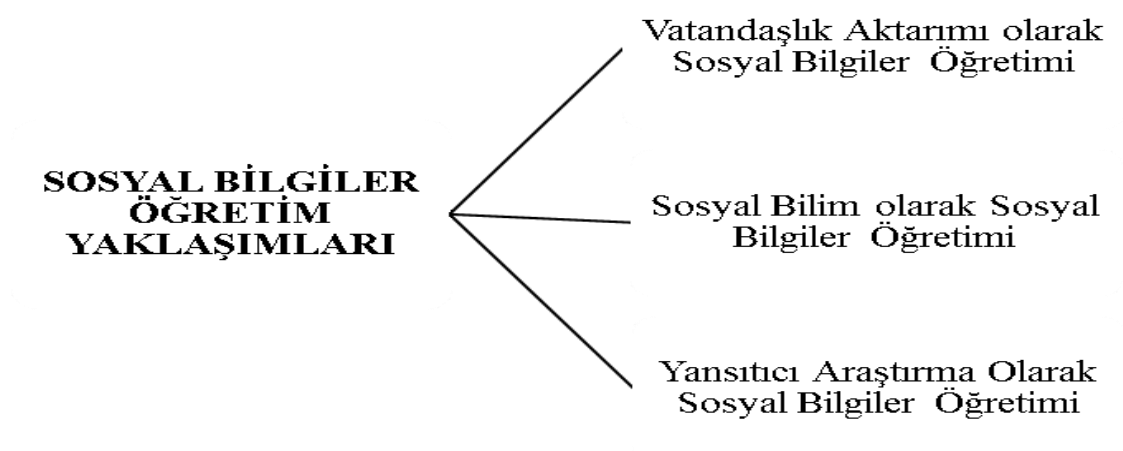

Sosyal bilgiler öğretimi alanında yaygın olan üç geleneğin içeriğine bakıldığında, vatandaşlık aktarımı olarak sosyal bilgiler öğretiminde, belli davranışları, bilgileri, bakış açılarını ve değerlerin öğrencilerin öğrenebilmesi için tasarlamış oldukları bir öğretim türünü yansıtır. Bu davranışlar, bilgiler vb. öğeler hem öğretmenin hem de öğrencinin katıldığı kültürel gelenektir. Yani iyi bir vatandaş, belli değerlere ve tutumlara sahip olan, kabul görmüş uygulamalara uyan ve kabul edilmiş yurttaşlık faaliyetlerine katılan biri olarak tanımlanır (Barr, Barth, \& Shermis, 1978). Bu bağlamda vatandaşlık aktarımının genel amacı, toplumun temel kurumlarının değerlerini, inançlarını ve öğretilerini telkin ederek, mevcut durumun devamını sağlamaktır (Öztürk, 2006).

Sosyal bilim olarak sosyal bilgiler öğretimi ise sosyal bilimlere ait bilgi, beceri ve değerlerin kazanılmasının etkili vatandaşlık için en iyi hazırlık olduğu varsayımına dayanır. Bu yaklaşıma göre öğrenciler, sosyal bilimlerin yapısı (onların temel kavramları, genellemeleri ve kuramları) ile bilgi toplama ve yorumlama süreçlerini 
öğrenmelidir. Bu nedenle sosyal bilimciler tarafından tanımlanan önemli bulgular, bakış açıları ve sorunlar, sosyal bilgiler programlarının içeriğini oluşturur (Öztürk, 2006). Çünkü sosyal bilgiler, birbiri ile ilişkili diğer sosyal sahalar arasında bağlantı kurmazsa dersin anlaşılması güçleşir. Onun için "birleştirme ve bağlantı kurma" sosyal bilgiler programında önemlidir (Moffatt, 1957). Çünkü sosyal bilgiler öğrenme alanlarında; tarih, coğrafya, ekonomi, sosyoloji, antropoloji, psikoloji, felsefe, siyaset bilimi ve hukuk gibi sosyal bilimler ile insan hakları, yurttaşlık ve demokrasi konuları disiplinler arası yaklaşımla bütünleştirilmiş olarak ele alınmaktadır (MEB, 2018). Bu doğrultuda sosyal bilim olarak sosyal bilgiler öğretimindeki temel amaç, öğrencilerin bir sosyal bilimcinin sorduğu türden sorular sormalarını ve sosyal bilimcinin analitik araçlarını ve kavramlarını kullanmalarını sağlamaktır. Ayrıca öğrenci belirli bir sosyal bilim disipliniyle ilişkili olan düşünce örneklerini ve zihin yapısını kazanırsa, farkları daha iyi görebilen biri olacaktır (Barr, Barth, \& Shermis, 1978).

Yansıtıcı araştırma olarak sosyal bilgiler öğretimine baktığımızda ise, John Dewey'in bu yaklaşıma temel bakış açıları geliştirdiğini görürüz. Dewey, eğitimin ne akademik disiplinlerden, ne de kültürel birikim değerlerinin aktarımından meydana gelmediğini belirterek, okul müfredatının öğrencilerin ilgi ve ihtiyaçlarından oluşması gerektiğini savunmuştur (Barr, Barth, \& Shermis, 1978). Çünkü yansıtıcı araştırma yaklaşımında öğrenci, kendi yaşamı içerisinde deneyim çizelgesini oluşturur. Özellikle öğrenci bu yaşantı içerisinde, öğrenme aktivitelerine katılarak problemler karşısında etkili çözüm ve karar verme anlayışı geliştirir (Ediger, 1988). Yansıtıcı araştırmada amaç, karar vermenin siyasal bir demokraside, vatandaşlığın en önemli gerekliliği olduğu için yansıtıcı araştırmayı destekleyenler, sosyal bilgilerin başlıca amacının öğrencilerin karar verme becerilerini geliştirmek olduğunu belirtmişlerdir. Çünkü karar veren bir kişi olarak tanımlanan vatandaş, bir sorunla karşılaştığında buna mümkün olduğunca mantıklı bir şekilde cevap verebilen kişidir (Barr, Barth, \& Shermis, 1978).

Alan yazına baktığımızda Cumhuriyetten günümüze (1924-2017) sosyal bilgiler öğretim programları ile ilgili pek çok çalışma yapıldığını görmek mümkündür (Akar, 2001; Akkuş, 2002; Ambarl1, 2010; Berk, 2008; Çelik, 2008; Çoban \& Akşit, 2018; Duman, 2011; Kaz, 2013; Keskin, 2002; Koçak, 1999; Koçoğlu, 2012; Koyuncu, 2015; Nalçac1, 2001; Özbey, 2001; Pirinçdane, 1997; Semenderoğlu \& Gülersoy, 2005; Şahin, 2009; Taş \& Kıroğlu, 2018; Tay, 2017; Yalnız, 2007; Yaman, 1999; Yazıc1, 2008; Yeşil, 1996; Yıldız, 2008). Ayrıca sosyal bilgiler öğretim yaklaşımları ile ilgili yapılmış çalışmalara da rastlamak mümkündür (Doğanay \& Sarı, 2004; Kozan, 2002; Özmen, 2010; Özmen, 2011a; Özmen, 2011b; Kaymakç1 \& Ata, 2012). Fakat alan yazın taramasında Türkiye'de, Cumhuriyetten günümüze kadar yayınlanan (1924-2017) sosyal bilgiler öğretim programlarında, sosyal bilgiler öğretim yaklaşımlarını ele alan bir çalışmaya rastlanmamıştır.

Sosyal bilgiler dersi yetiştirmeyi hedeflediği "iyi ve etkin” vatandaş çizgisine öncelikle mevcut programdaki hedefler doğrultusunda şekil verir. Dönemin ihtiyaçları, yaşanan sosyal değişiklikler, bilim ve teknolojideki yenilikler sosyal bilgiler programının genel amaçlarını sürekli günceller. Programların amaçları her ne kadar zaman ve sürekliliğe bağlı olarak güncellense de özünde hep "iyi-etkin" vatandaş1 yetiştirme gayesi yatar. Böylece sosyal bilgiler dersi bu gayeyi öğrenciye ulaştıran öğretmeni ve ona yön veren programın sosyal bilgiler öğretim yaklaşımı ile yakalar. Öğretmenin benimsediği sosyal bilgiler öğretim yaklaşımı kadar programın ona 
sunduğu olanaklar ve kısıtlamalarda dersin havasını etkiler. O nedenle cumhuriyettin ilk yıllarından bugüne kadar olan sosyal bilgiler öğretim programında hangi öğretim yaklaşımın baskın olduğunu anlamak, o dönem sınıf içinde oluşan öğretim anlayışını keşfetmek adına önemlidir, diyebiliriz.

Sosyal bilgiler öğretim yaklaşımları ülkemizde sosyal bilgiler öğretiminin gelişimi ve algılanışında önemli bir etkiye sahip olmuştur. Merkezine iyi ve sorumlu vatandaşlık, insan ve toplum gibi kavramları alan sosyal bilgiler (Kaymakçı \& Ata, 2012), bu hedefe sosyal bilgiler öğretim yaklaşımları aracılığı ile ulaşmayı hedefler. Bu nedenle değișen programlar etkilendikleri felsefi akımın etkisi ve dönemin iyi vatandaştan beklentisi üzerine imar ettiği sosyal bilgiler öğretim yaklaşımını benimser. $\mathrm{Bu}$ doğrultuda çalışmanın temel amacı, Cumhuriyetten günümüze kadar yapılmış olan 1924, 1930, 1938, 1948, 1961, 1968, 1990 ilkokul programlar1, 1932, 1938, 1949, 1962, 1970, 1985 ortaokul programları, 1998 ve 2005 ilköğretim sosyal bilgiler programları ve 2017 ilkokul ve ortaokul sosyal bilgiler programlarının sosyal bilgiler öğretim yaklaşımlarına göre (vatandaşlık aktarımı olarak sosyal bilgiler, sosyal bilim olarak sosyal bilgiler ve yansitıcı araştırma olarak sosyal bilgilere) nasıl bir gelişim izlendiğini ortaya koymaktır.

\section{Yöntem}

\section{Araştırmanın Modeli}

$\mathrm{Bu}$ araştırmada, cumhuriyetten günümüze sosyal bilgiler öğretim programları incelendiği için tarama modeli içinde yer alan tarihsel yöntem kullanılmıştır. Tarama yöntemi (alan yazın taraması), geçmişte ve halen var olan bir durumu mevcut şekliyle betimlemeyi amaçlayan yaklaşımlardır. Alan yazın taraması, araştırma probleminin seçilerek anlaşılmasına ve araştırmanın tarihsel bir perspektife oturtulmasına yardımcı olur (Karasar, 2006). Bilindiği gibi derinlemesine incelenen belgeler, becerikli ve düşünce dünyası geniş olan bir araştırmacı için hazır bilgi kaynağıdır. Ayrıca tarihsel araştırmalar, temel olarak betimleyici bir özelliğe sahiptir (Merriam, 2013). Bu yöntem, gerçeği bulmak, başka bir deyişle, bilgi üretmek için geçmişin eleştirel bir gözle incelenmesi, analizi, sentezi ve rapor edilme sürecini kapsamaktadır (Kaptan, 1998).

\section{Verilerin Toplanması}

Araştırmada, tarama modeli içinde yer alan tarihsel yöntem kullanıldığı için öncelikli olarak konuyla ilgili alan yazın taraması yapılmıştır. Bunun sonucunda, araştırma konusuyla ilgili dokümanlar olan, cumhuriyetten günümüze yayınlanmış ilkokul programları $(1924,1930,1938,1948,1961,1968$ 1990), ortaokul programlar1 (1932, 1938, 1949, 1962, 1970, 1985), ilköğretim programları (1998 ve 2005) ve ilkokul ve ortaokul (2017) programı, Talim Terbiye Kurulu Kütüphanesi, Milli Kütüphane ve MEB resmi internet sitesinden birinci yazar tarafindan taranarak toplanmıştır.

Kaynaklar içerisinde yer alan Osmanlıca yazılmış olan 1924 programı, tarih eğitimi alanından bir uzman tarafından Türkçeye çevrilmiştir. Toplanan bu dokümanlar ile birlikte üniversitelerde, sosyal bilgiler eğitimi alanında hazırlanan yüksek lisans ve doktora tezleri, Yüksek Öğretim Kurumu elektronik tez arşivinden taranmıştır. Bunun 
yanı sıra kütüphane ve internet yoluyla daha önce konu ile ilgili yapılmış araştırmalar ve makaleler incelenmiştir.

Araştırmada temel veri olarak kullanılan kaynaklar aşağıda gösterilmiştir:

- 1924 (1340) Musahabat-ı Ahlakiye ve Malumat-ı Vataniye

- 1930 ve 1938 Ilk Mektep Yurt Bilgisi

- 1948 ve 1961 İlkokul Yurttaşlık Bilgisi

- 1968 ve 1990 Ilkokul Sosyal Bilgiler

- 1932 ve 1938 Orta Mektep Yurt Bilgisi

- 1949, 1962 ve 1970 Ortaokul Yurttaşlık Bilgisi

- 1985 Ortaokul Vatandaşlık Bilgileri

- 1998 ve 2005 İlköğretim Sosyal Bilgiler

- 2017 Illkokul ve Ortaokul Sosyal Bilgiler

\section{Verilerin Analizi}

Araştırmada, alan yazın taraması sonucunda toplanan veriler, betimsel analiz tekniğine dayalı olarak analiz edilmiştir. Dokümanların analizinde kullanılan betimsel analizin amacı, elde edilen bulguların düzenlenerek bu bulguları, yorumlanmış bir biçimde okuyucuya sunmaktır. $\mathrm{Bu}$ nedenle doküman incelemesi, araştırılması hedeflenen olgu veya olgular hakkında bilgi içeren yazılı materyallerin analizini kapsamaktadır. Özellikle eğitim alanında ders kitapları, program (müfredat) yönergeleri gibi dokümanlar, eğitim araştırmalarında veri kaynağı olarak kullanılabilmektedir (Yıldırım \& Şimşek, 2006).

Bilindiği gibi nitel araştırmalarda geçerliliği ve güvenirliğini arttırmak için araştırmanın her bir aşamasında izlenen yol detaylı olarak tanımlanmaktadır. Bu özellikle veri kaynağının kullanılması ve tutarlılığın incelenmesi, sonuçların güvenirliğine ilişkin bilgi vermektedir (Büyüköztürk, Çakmak, Akgün, Karadeniz, \& Demirel, 2014). Bu nedenle bu çalışmada öncelikle ilk elden kaynaklar (dönemin ilkokul, ortaokul ve ilköğretim programlarında sosyal bilgiler dersi kapsamına giren derslerin içerikleri) temin edilmiş ve araştırmanın amacı doğrultusunda incelenecek ölçütlere karar verilmiştir. Sosyal bilgiler öğretim yaklaşımları için mevcut üç yaklaşım olan "vatandaşlık aktarımı olarak sosyal bilgiler yaklaşımı, sosyal bilimler olarak sosyal bilgiler yaklaşımı, yansıtıcı araştırma olarak sosyal bilgiler yaklaşımı" ortak temalar olarak kabul edilmiştir. Bu temalar altında sosyal bilgiler öğretim yaklaşımlarının özelliklerini ve içeriğini yansıtan ifadeler tespit edilmiştir. Analizler, araştırmanın geçerlik ve güvenirliğini arttırmak için araştırmacıların dışında iki sosyal bilgiler alan uzmanının katılımı ile gerçekleştirilmiş ve bulgular, programlardan yapılan doğrudan alıntılarla desteklenmiştir.

\section{Bulgular ve Yorum}

$\mathrm{Bu}$ bölümde, cumhuriyetten günümüze sosyal bilgiler dersi öğretim programlarının sosyal bilgiler öğretim yaklaşımlarından olan "vatandaşlık aktarımı olarak sosyal bilgiler ögretimi, sosyal bilim olarak sosyal bilgiler ögretimi ve yansitıcı araştırma olarak sosyal bilgiler ögretimi" başlıklarında analiz edilerek bunun sonucunda elde edilen bulgulara yer verilmiştir. 


\section{Vatandaşlık Aktarımı Olarak Sosyal Bilgiler Öğretim Yaklaşımına Göre Bulgular}

1924 (1340) Musahabat-ı Ahlakiye ve Malumat-ı Vataniye Dersi Öğretim Programı. Cumhuriyet döneminin ilk programı olan 1924 İlk Mektep Müfredat Programında, sosyal bilgiler dersi öğretimi kapsamında yer alan musahabat-1 ahlakiye ve malumat-1 vataniye dersi aracılığ hedeflenmiştir. 1924 İlk mektep programındaki musahabat-1 ahlakiye ve malumat-1 vataniye dersi, öncelikle yeni kurulan Türkiye Cumhuriyetinin oluşturmak istediği iyi vatandaş profilini göstermektedir. Özellikle cumhuriyet ideolojisine uygun vatandaş oluşturma anlayışı bu dönemde etkin rol kazanmıştır. Vatandaşlık aktarımının temel özelliği toplumun kendine ait kültürel değerlerini yetiştirilmek istenen bireylere öğretilmesidir. Programda yer alan örnek bulgulardan bazıları şunlardır:

"Musahabet-i Ahlakiye ve Ma'lumat-1 Vataniye derslerinin gayesi, gençlere Türkiye Cumhuriyeti'nin bir vatandaşı olmak sıfatıyla malik oldukları hak ve vazifeleri tanıtmak, bütün hareketlerinde hâkim olması lazım gelen ahlak esaslarını telkin itmek, velhasıl milli ve insani vazifelerini takdir ve ifa edebilecek bir hale getirmektir" (Maarif Vekâleti, 1924, s. 28).

"Mekteplerimizden yetişen gençler, bil-zat tecrübeleriyle en muvafik ve en mükemmel tarz idarenin cumhuriyet idaresi olduğunu fa'len öğrenmiş ve icabında onu müdafaa ve himaye için hiçbir fedakârlıktan çekinmeyecek bir hale gelmiş olurlar” (Maarif Vekâleti, 1924, s. $31)$.

Burada yer alan açıklamalara göre cumhuriyet yönetimini anlayan, cumhuriyetin niteliklerini benimseyen, kendi ülkesindeki vatandaşlık sorumluluklarını bilen bir ideal vatandaş tipinin oluşturulmaya çalışıldığını göstermektedir. Ayrıca devletin kendine ait milli ve insani değerlerini öğrenciye yansıtması ve cumhuriyetin temel niteliklerine sahip bir neslin oluşturulması, vatandaşlık değerlerinin aktarımı açısından önemli olduğu söylenilebilir. Bu doğrultuda 1924 programında yer alan musahabat-1 ahlakiye ve malumat-1 vataniye dersinin, sosyal bilgiler öğretim yaklaşımlarından vatandaşlık aktarımına önem verdiği ve programda temel amacın iyi vatandaş yetiştirme olduğu düşünüldüğünde, vatandaşlık aktarımına hizmet ettiği söylenebilir.

1930 Yurt Bilgisi Dersi Öğretim Programı. Cumhuriyet tarihinin ikinci ilkokul programı olan 1926 programının 1927 ve 1930 basımları da bulunmaktadır (Keskin, 2009). Bu çalışmada, 1930 basımı olan ilk mektep müfredat programında yer alan yurt bilgisi dersi öğretim programı incelenmiştir. Sosyal bilgiler kapsamında yer alan yurt bilgisi dersi öğretim programı, vatandaşlık aktarımının özellikleri açısından incelendiğinde, öğrencinin kendi hak, görev ve sorumluluklarını bilen; toplumsal yaşamdaki sorunlara duyarlı olan ve bu sorunlara çözüm üretebilen bir vatandaş anlayışı oluşturulmaya çalışıldığı söylenebilir. Programda yer alan örnek bulgulardan bazıları şunlardır:

"Muallim tarihi önemli şahsiyetlerin isimlerini, tarihi ehemmiyeti olan kısımları öğretecek ve Milli şuur uyandırma ve eski şahsiyetler hakkında bilgi verecektir" (Maarif Vekâleti, 1930, s. 77).

"Bu ders diğer dersler için adeta bir telakki ve temerküz sahası teşkil eder. İlk tahsilin birinci amacı vatandaş yetiştirme, gençleri mensup oldukları vatan ve millete intibak ettirmektir. Bu ders bir merkez ve mihveri mahiyetindedir" (Maarif Vekâleti, 1930, s. 78). 
1930 İlk Mektep Müfredat Programında yer alan örnek bulgularda, vatandaşlık değerleri açısından önemli olan tarihe mal olmuş önemli şahsiyetlerin hayatları, milli bilinç ve kültürel değerlere vurgu yapılmıştır. Bununla beraber, ilk mektebin temel amacının vatandaş yetiştirmek olduğu ayrıca gençlerin mensup olduğu milletin temel değerlerini öğrenilmesi üzerinde durulmuştur.

1948 Yurttaşık Bilgisi Dersi Öğretim Programı. 1948 programının amaçları, ilkeleri ve açıklamaları; çocuğun bir vatandaş olarak kişiliğini her yönden bir bütün olarak yetiştirmeyi amaç edinmiştir (Arslan, 1999). Programda geçen örnek bulgulardan bazıları şunlardır:

"Ulus ve yurt işlerine karşı öğrencilerde yakın ilgi uyandırmak, ulus ve yurt işlerini her işin üstünde tutmayı ulus ve yurda karşı canla başla hizmet etmeyi; çocuklarda alışkanlık ve ülkü haline getirmektir.” (MEB, 1948, s. 142).

"Öğrencileri cumhuriyetçi, ulusçu, halkçı, devletçi, laik ve devrimci birer yurttaş olarak yetiştirmek için ilk adımı atmaktır" (MEB, 1948, s. 142).

"Türk devriminin manasını, ayrı ayrı yönlerden önemini, Türkiye'nin saadet ve refahını yaptığı ve yurdun geleceğine yapacağı etkiyi öğrencilere kavratmak ve onları Türk devriminin değerlerine bağlı ve bunları her zaman korumaya hazır, fedakâr birer Türk evladı olarak yetiştirmektedir" (MEB, 1948, s. 143).

1948 İlkokul Programında, vatandaşlık aktarımının özellikleri genel olarak değerlendirildiğinde, kültür aktarımı ve özellikle milletin sahip olduğu eski tarihi kişiliklerin yaşamları, birliktelik, dayanışma gibi kültürel değerleri ayakta tutan kavramlara vurgu yapıldığg söylenebilir. Böylece öğrenci, Türk ulusunun sahip olduğu değerleri öğrenmesi üzerinde durulmuştur.

1961 İlkokul Yurttaşlık Bilgisi Dersi Öğretim Programı. 1961 İlkokul Yurttaşlık Bilgisi Dersi Öğretim Programı, vatandaşlık aktarımı yaklaşımının özelliklerine göre incelendiğinde, öğrenciyi iyi bir yurttaş olarak yetiştirmek için vatana ve millete canla başla hizmet etme ve bazı değerlere bağlı olma; bunu kendi yaşamında adeta bir ülkü ve inanç haline getirilmesi gerektiği söylenebilir. Programda yer alan örnek bulgulardan bazıları şunlardır:

"Türk milletinin amaç ve ülkülerini öğrencilere benimsetmek, bunları gerçekleştirmek için her türlü fedakârllı̆ı göze alacak ülkülü yurttaşlar yetiştirmek önemlidir” (MEB, 1961, s. 148).

"Türk ulusunun değerlerine bağl1lığı güçlendirmek, kendilerini Türk milletinin ülkülerini gerçekleştirmek için her fedakârlığı göze alabilecek bir karakterde yetiştirmektir” (MEB, 1961, s. 147).

Açıklamalardan da anlaşıldığı gibi bir milletin amaç ve ideallerini gerçekleştirebilecek yurttaşlar yetiştirmeyi hedeflediği görülmektedir.

1968 İlkokul Sosyal Bilgiler Dersi Öğretim Programı. 1968 İlkokul Sosyal Bilgiler Dersi Öğretim Programı, vatandaşlık aktarımının özellikleri açısından değerlendirildiğinde, programın nitelikli yurttaşlar yetiştirme adına önemli adımlar attı̆ğ saptanmıştır. Programda yer alan örnek bulgulardan bazıları şunlardır:

"Yurttaşlık görevleri ve sorumlulukları yönünden, Türk çocuklarını, Türk devrim değerlerine bağll1ıklarını kuvvetlendirmek, çocuklara şerefli bir geçmişi olan büyük bir milletin evlatları olduklarını duyurarak onların Türk ulusunun geleceğine olan güvenlerini artırmak ve kendilerini Türk milletinin ülkülerini gerçekleştirmek için her fedakârllğ̆ göze alabilecek bir karakterde yetiştirmektir" (MEB, 1968, s. 63). 
$\mathrm{Bu}$ açıklamalardan da anlaşıldığı gibi 1968 İlkokul Sosyal Bilgiler Dersi Öğretim Programı, vatandaşlık aktarımının özellikleri kapsamında değerlendirildiğinde, kültürel değerlere çok fazla vurgu yapılmadığı belirlenmiştir. Ancak geçmişe mal olmuş tarihi kişiliklerin yaşamları ve milletin temel toplumsal değerleri az da olsa programa yansıtılmak istendiği söylenilebilir. Bununla birlikte, ülkesi için canla başla hizmet eden ve bunu yaşamında bir ülkü ve inanç haline getiren vatandaşlık anlayışına vurgu yapıldığı yorumlanabilir. Ayrıca 1968 Sosyal Bilgiler Dersi Öğretim Programı, devletin ve milletin geçmiş kültür değerlerini öğrenciye yansıtmak ve bu değerleri onlarda bir bilinç kazandırma amacı taşıdı̆̆ı söylenebilir.

1990 İlkokul Sosyal Bilgiler Dersi Öğretim Programı. 1990 İlkokul Sosyal Bilgiler Dersi Öğretim Programı, vatandaşlık aktarımının özellikleri açısından incelendiğinde, vatandaşl1k görevleri ve sorumlulukları yönünden yetiştirilmek istenen insan niteliklerine değinildiği söylenebilir. Özellikle aile, millet ve vatan üçgenindeki değerlerin ön planda olduğu saptanmıştır. Programda yer alan örnek bulgulardan bazıları şunlardır:

"Vatandaşlık görevleri yönüne vurgu yapan bir başka amaç ifadesi ise her yönde görev ve sorumluluk alabilecek hale gelir. Aile bütünlüğüne bağlllık kazanır. Ailenin refah ve mutluluğu için sorumluluk ve görev duygusuyla hareket eder” (MEB, 1990, s. 329).

1990 İlkokul Sosyal Bilgiler Dersi Öğretim Programı, vatandaşlık aktarımı kapsamında dikkat çeken "iyi insan iyi vatandaş” vurgusu son derece önemlidir.

1932 Orta Mektep Yurt Bilgisi Dersi Öğretim Programı. 1932 Orta Mektep Müfredat Programında yer alan yurt bilgisi dersi, vatandaşlık aktarımı açısından değerlendirildiğinde, yeni kurulan devletin temel vatandaşlık değerlerinin benimsetilmeye çalışıldığı söylenilebilir. Özellikle programda demokrasi, cumhuriyet, hak, anayasa ve devletin temel inkılaplarına vurgu yapıldığı saptanmıştır. Böylece ögrenci, elde ettiği bilgiler sonucunda cumhuriyetin niteliklerine uygun bir vatandaşlik anlayışı oluşturulmak istenmiştir. Programda yer alan örnek bulgulardan bazıları şunlardır:

"Öğrendiği bilgileri ve kazandığı bu kabiliyetler ile talebenin milliyet ve vatan merbutiyetinin, insanlık duygularının daha şuurlu ve köklü bir hale getirmesi, cumhuriyet vatandaşlı̆ıını daha ziyade liyakat ve kudretle ifa edebilecek bir seviyeye gelmesidir" (Maarif Vekâleti, 1931, s. 34-37).

Bu açıklamalara göre 1932 Yurt Bilgisi Dersi Öğretim Programı, sosyal bilgiler öğretim yaklaşımlarından vatandaşlık aktarımına önem verdiğini söylemek mümkündür.

1938 Orta Mektep Yurt Bilgisi Dersi Öğretim Programı. 1938 Orta Mektep Yurt Bilgisi Dersi Öğretim Programı, vatandaşlık aktarımı yaklaşımına göre değerlendirildiğinde, devletin temel vatandaşlık değerlerine temas edildiği saptanmıştır. Ayrıca milletin sahip olduğu temel kültürel değerlerin aktarımına da vurgu yapıldığı söylenebilir. Programda yer alan örnek bulgulardan bazıları şunlardır:

"Millet olgusu ve milletin sahip olduğu kültürel ve manevi değerler, vatandaşların devlete olan katkısı, vatandaşların hak ve vazifelerini etkin bir şekilde kullanabilmeleri" (Kültür Bakanlığı, 1938).

1938 Orta Mektep Yurt Bilgisi Dersi Öğretim Programında, yeni cumhuriyet vatandaşlığının oluşması için hem geçmişin önemli kültürel değerleri hem de 
cumhuriyetin temel nitelikleri birleştirilerek ideal vatandaşlık tipi oluşturulmaya çalışıldığı söylenebilir.

1949 Ortaokul Yurttaşık Bilgisi Dersi Öğretim Programı. 1949 Ortaokul Yurttaşlık Bilgisi Dersi Öğretim Programı, vatandaşlık aktarımı açısından incelendiğinde, vatandaşlık aktarımına uygun içeriklerin olduğu saptanmıştır. 1949 Ortaokul Yurttaşlık Bilgisi Dersi Öğretim Programında dönemin şartları gereği vatandaşlık aktarımına ait özelliklerin yoğun olduğu söylenilebilir. Özellikle 1945 'ten sonra 2. Dünya Savaşının etkisiyle, yeni neslin; devlete ve millete bağlı, ülkesi için canla başla mücadele eden bir vatandaşlık anlayışı oluşturulmak istendiği söylenilebilir. Programda yer alan örnek bulgulardan bazıları şunlardır:

"Yurttaşlık bilgisi dersinde, milli birlik ve dayanışmanın, milli disiplinin manasını ve önemini çocuklara kavratmak gerekir. Öğretmen millet için yaşamanın, millet için ölmenin, millete bütün varlığını, benliğini vermenin Türk çocuğunun ödevi ve ülküsü olduğunu, milli amaçlara gerçekleştirmenin her amacın üstünde bulunduğunu çocuklara aşılamalıdır." (MEB, 1949, s. 115).

$\mathrm{Bu}$ açıklamalarda öğrenciler, etkin birer vatandaş olabilmeleri amacıyla kanunları ve haklarını bilen, kendi milli kültürel değerleri özümsemiş, toplum içerisine katılarak etkin kararlar alabilen bir ideal vatandaşlık anlayışı oluşturulmak istenmiştir.

\section{Ortaokul Yurttaşık Bilgisi Dersi Öğretim Programı.}

1962 Ortaokul Yurttaşlık Bilgisi Dersi Öğretim Programında, vatandaşlık aktarımı yaklaşımına göre şu bulgulara ulaşılmıştır:

"Yurttaşlık bilgisi derslerinde milli birlik ve dayanışmanın, milli disiplinin manasını ve önemini çocuklara kavratmak gerekir. Öğretmen millet için yaşamanın, millet için ölmenin, millete bütün varlığını, benliğini vermenin Türk çocuğunun ödevi ve ülküsü olduğunu, milli amaçlara gerçekleştirmenin her amacın üstünde bulunduğunu çocuklara aşılamalıdır." (MEB, 1962, s. 134).

1962 Ortaokul Yurttaşlık Bilgisi Dersi Öğretim Programının içeriği genel olarak değerlendirildiğinde, Türk milletine ait değerlerin varlığını yaşatmaya, devlete ve millete bağl1lı̆̆ın güçlendirilmesine, birlik ve beraberlik duygusuna sahip bilinçli yurttaşlar yetiştirmeye vurgu yapıldığı saptanmıştır. Öğrencilerin, milli kültürel değerleri özümsemiş, toplum içerisine katılarak etkin kararlar alabilen bir ideal vatandaşlık anlayışıyla oluşturulmak istendiği söylenilebilir. Bunun sonucunda, ülkesi için canla başla mücadele eden bir vatandaşlık anlayışı hedeflenmiştir.

1970 Ortaokul Yurttaşlık Bilgisi Dersi Öğretim Programı. 1970 Ortaokul Yurttaşlık Bilgisi Dersi Öğretim Programında, vatandaşlık aktarımı yaklaşımına uygun özelliklere ulaşılmıştır:

"Millet ve yurt işlerine karşı öğrencilerde yakın ilgi uyandırarak bu işleri her işin üstünde tutmayı, ulusa ve yurda canla başla hizmet etmeyi alışkanlık ve ülkü haline getirmektir." (MEB, 1970, s. 131).

"Okulda demokratik zihniyetin hakim olduğu bir hava yaratarak öğrencilerin kendi kendilerini yönetmelerine okul içinde veya okul dışında sorumlu işler almalarına geniş olanak ve firsatlar sağlama" (MEB, 1970, s. 132).

Bu açıklamalara dayalı olarak 1970 Ortaokul Yurttaşlık Bilgisi Dersi Öğretim Programında vatandaşlık aktarımının özelliklerine yer verildiği söylenilebilir. 
Programda, öğrencileri etkin birer vatandaş ve ülkesi için canla başla hizmet eden nitelikli kişiler yetiştirmek amacı taşıdığı söylenilebilir. Bu doğrultuda kanunları ve haklarını bilen, milli, kültürel değerleri özümsemiş, toplum içerisine katılarak etkin kararlar alabilen bireyler yetiştirmeyi amaçlamaktadır.

1985 Ortaokul Vatandaşlık Bilgileri Dersi Öğretim Programı. 1985 Ortaokul Vatandaşlık Bilgileri Dersi Öğretim Programında, vatandaşlık aktarımının özellikleri kapsamında incelendiğinde şu bulgulara ulaşılmıştır:

"Öğretmen, yurttaşlık bilgileri dersinde toplumun her üyesinin birbirine karşı sevgi, saygı ve muhabbet duymaları ve birbirleriyle işbirliği içerisinde yardımlaşma ve dayanışma duygusuyla hareket edilmelidir. Ayrica aktüel olaylardan hareket ederek 'iyi insan iyi vatandaş' anlayışına açıklık getirilmelidir." (MEB, 1988, s. 207-208).

$\mathrm{Bu}$ bulgulara göre 1985 Ortaokul Vatandaşlık Bilgisi Dersi Öğretim Programında, vatandaşlık aktarımına ait özelliklere yer verildiği saptanmıştır. Programda, vatandaşlık aktarımına vurgu yapıldığı, "iyi insan iyi vatandaş" anlayışına sahip kişinin, toplumsal sorunlara karşı duyarlı olduğu üzerinde durulmuştur. Yani iyi insan iyi vatandaş, toplumsal sorunlara duyarl1, güncel olaylar üzerine düşünen ve birbiriyle iş birliği, yardımsever ve dayanışma içerisinde bulunan bireylerdir.

1998 İlköğretim Sosyal Bilgiler Dersi Öğretim Programı 1998 İlköğretim Sosyal Bilgiler Dersi Öğretim Programı, vatandaşlık aktarımı yaklaşımı açısından incelendiğinde şu bulgulara ulaşılmıştır:

"Ailesine, milletine, vatanına Atatürk inkılap ve ilkelerine bağlı çalışkan, araştırıcı, inceleyici, fedakâr ve fazilet sahibi iyi bir insan iyi bir vatandaş olarak yetişirler" (MEB, 1998, s. 329).

"Millet ve yurt işlerini her şeyin üstünde tutarak milleti ve yurdu için canla başla hizmet etmeyi alışkanlık ve ilke haline getirmektir" (MEB, 1998, s. 332).

1998 İlköğretim Sosyal Bilgiler Dersi Öğretim Programı, genel olarak değerlendirildiğinde, vatandaşlık aktarımı açısından önemli olan, kültürel değerlere vurgu yapıldığı, bu nedenle vatandaşlık aktarımına hizmet ettiği söylenebilir.

2005 İlköğretim Sosyal Bilgiler Dersi Öğretim Programı. 2005 Sosyal Bilgiler Dersi Öğretim Programı, vatandaşlık aktarımının özellikleri açısından incelendiğinde, öncelikle öğrenciye temel vatandaşlık becerilerini kazandırmak ve kültürel değerlerin taşıyıcısı olduğu bilinci yerleştirmek olduğu görülmektedir. Bu doğrultuda program, öğrencilere kültürel öğelerin toplumun ulusal kimliğini oluşmasında ne kadar önemli olduğunu fark etmelerini hedeflemektedir. Programda yer alan örnek bulgulardan bazıları şunlardır:

"Türkiye Cumhuriyeti vatandaşı olarak hak, özgürlük ve sorumluluklarının bilincinde, demokratik hayata etkin bir şekilde katılarak karşılaşıtı̆ı sorunlara barışçıl çözümler üreten, yaşamın her alanında hoşgörü ve uzlaşma kültürünün oluşmasına ve gelişmesine katkı sağlayan bireyler olmalarını sağlamaktır" (MEB, 2005).

$\mathrm{Bu}$ açıklamalara dayalı olarak 2005 Sosyal Bilgiler Dersi Öğretim Programı vatandaşlık aktarımı yaparken kendi öz değerlerini korurken çağdaş değerleri de benimsetmeyi amaçlamıştır. Aslında yetiştirilmek istenen vatandaş profili de içinde bulunduğumuz yüzyılın koşullarına göre şekillenmiştir. Bu nedenle 2005 Sosyal Bilgiler Dersi Öğretim Programı da bunu en belirgin şekilde yansıtan program olmuştur.

"Ülkemizin diğer ülkelerle olan ekonomik ilişkilerini, kaynaklar ve ihtiyaçlar açısından değerlendirir” (MEB, 2005, s. 20). 
"Uluslararası bilim, kültür, sanat, fuar ve spor etkinliklerinin toplumlararası etkileşimindeki rolünü değerlendirir” (MEB, 2005, s. 20).

$\mathrm{Bu}$ bağlamda yetiştirilmek istenen vatandaş, dünya platformunda ülkesini en iyi temsil eden bireylerdir. Örnek kazanımlardan da anlaşıldığ aktarımı daha evrensel boyutta verilmeye çalışıldığı yorumlanabilir.

\section{7 İlkokul ve Ortaokul Sosyal Bilgiler Dersi Öğretim Programı.}

2017 İlkokul ve Ortaokul Sosyal Bilgiler Dersi Öğretim Programı, vatandaşlık aktarımının özellikleri kapsamında incelendiğinde, bireyin topluma ve kültüre katk1 sağlayan, toplumsal ve evrensel değerleri kavrayarak gelecek nesillere aktaran bir misyona sahip olduğu söylenebilir. Vatandaşlık aktarımı zamanla değişmiş ve ülkesini dünya platformunda en iyi temsil eden, 21. yüzyıl becerilerine sahip, evrensel değerleri ön plana alan vatandaşın hedeflendiği dikkat çekmektedir. Vatandaşlık aktarımı yaklaşımı açısından incelendiğinde şu bulgulara ulaşılmıştır:

"Türk kültürünü ve tarihini oluşturan temel öge ve süreçleri kavrayarak millî bilincin oluşmasını sağlayan kültürel mirasın korunması ve geliştirilmesi gerektiğini kabul etmeleri” (MEB, 2018, s. 8).

"Türkiye Cumhuriyeti vatandaşı olarak vatanını ve milletini seven, haklarını bilen ve kullanan, sorumluluklarını yerine getiren, millî bilince sahip birer vatandaş olarak yetişmeleri” (MEB, 2018, s. 8).

"Millî, manevi değerleri ile evrensel değerleri benimseyerek erdemli insan olmanın önemini ve yollarını bilmeleri" (MEB, 2018, s. 8).

2017 İlkokul ve Ortaokul Sosyal Bilgiler Dersi Öğretim Programı, vatandaşlık aktarımı açısından değerlendirildiğinde; vatanseverlik, aile birliğine önem verme, dayanışma, yardımseverlik gibi değerlere temas edildiği; kültür, kültürel miras, milli bilinç, toplum ve değerler gibi kavramlara vurgu yapıldığı ayrıca milli ve dini bayramlar, önemli gün ve haftaların tarihsel duyarlılı̆̆ geliştirerek milli bilinci uyandırma gibi öğelere vurgu yapılması vatandaşlık aktarımına dair özellikler olarak yorumlanabilir.

\section{Sosyal Bilim Olarak Sosyal Bilgiler Öğretimi Yaklaşımına Göre Bulgular}

\section{4 (1340) Musahabat-ı Ahlakiye ve Malumat-ı Vataniye Dersi Öğretim}

Programı. 1924 programı tek disiplinli anlayışa sahip olsa da (Keskin, 2009), sosyal bilimlerin disiplinlerinin varlığını program içerisinde görmek mümkündür. Bu noktadan bakıldığında sosyal bilimler disiplinlerinden; hukuk, ekonomi, siyaset bilimi, tarih gibi disiplinleri öğretme gayesi hâkim olduğu söylenebilir. Program içerisinde geçen disiplinlerle ilgili bazı örnek açıklamalar şunlardır:

Hak ve vazife. Hak ve mes'uliyet. Hayır ve şer. Fazilet ve hak ve vazifelerimiz (nefsimize, ailemize, milletimize, beşeriyete karşı) hemşehrilik vazifeleri (Maarif Vekâleti, 1924. s, 33).

Belediyeler, belediyelerin vazifeleri, belediyelerin şehr halkının sahtını te'min için ittihaz edecekleri tedbirler (Maarif Vekâleti, 1924, s. 33).

"Devletin iktisadi hayata aid vazifeleri: halkın hayat ve sıhati ve refahı ile alakadar olan umumi meselelere karşı devletin vaziyeti. İktisadi hayatı umumiye namına devletin müdahalesi. Posta, telgraf, telefon; tenvirat, su, mezbahalar, yollar, kanallar, limanlar ve madenler gibi mes'elelerde devletin münasebeti. Hayat pahalılı̆̆ına, ihtikâra, mesken buhranına karşı halkın lehine tedbirler ittihazı" (Maarif Vekâleti, 1924, s. 36). 
1924 programında, özellikle sosyal bilim disiplinlerinden, tarih, siyaset bilimi, hukuk, ekonomi ve sosyoloji disiplinlerine vurgu yapan konu başlıkları ve içeriğine değinilmiştir. $\mathrm{Bu}$ doğrultuda 1924 programında, sosyal bilimler olarak sosyal bilgiler yaklaşımının olduğunu söylemek mümkündür.

1930 Yurt Bilgisi Dersi Öğretim Programı. 1930 İlk Mektep Müfredat Programında yer alan yurt bilgisi dersi öğretim programını, sosyal bilimler yaklaşımının özelliklerine göre değerlendirildiğinde, diğer derslerle ilişki kurulduğu saptanmıştır. Programda yer alan örnek bulgulardan bazıları şunlardır:

"Vergiler, belediye bütçeleri, ticaret, sanayi ve iktisadi mıntıkaları" öğretilecektir (Maarif Vekâleti, 1930, s. 82-85).

"Yurt bilgisi diğer farklı disiplin alanlarının mihveri konumunda olduğu gibi onlardan da faydalanmaktadır. Coğrafya, Tarih, Türkçe dersleriyle pek ziyade münasebattadır”. (Maarif Vekâleti, 1930, s. 80).

“Ayrılık ve topluluk insanın büsbütün yalnız yaşamasının imkânsızlı̆̆ı, cemiyet hayatının zarureti; İnsanlar arasında iş bölümü ve birlikte yapılan iş, insanların birbirine istinad, zarureti, tesanüt. Birlikte yapılan işte müşterek bir maksat vardır. Müşterek maksatlar müşterek ihtiyaçlardan doğar (Maarif Vekâleti, 1930, s. 81-82).

Bu açıklamalara göre 1930 İlk Mektep Yurt Bilgisi Dersi Öğretim Programında, sosyal bilimler yaklaşımı açısından değerlendirildiğinde, sosyal bilgiler öğretim yaklaşımlarından sosyal bilimlere ait birden fazla disiplin ile (siyaset bilimi, hukuk, ekonomi ve sosyoloji) ilişkilendirildiği tespit edilmiştir.

1948 Yurttaşlık Bilgisi Dersi Öğretim Programı. 1948 İlkokul Yurttaşlık Bilgisi Dersi Öğretim Programı sosyal bilim yaklaşımının özellikleri açısından incelendiğinde, programın farklı disiplinlerle ilişkilendirildiği görülmektedir. Programda yer alan örnek bulgulardan bazıları şunlardır:

"Yurttaşlık bilgisi dersi daima başka derslerle ilgisi göz önünde bulundurulacaktır. Örneğin cumhuriyet rejiminin başka rejimlere üstünlüğünü, Türk devriminin ayrı ayrı cephelerini öğrencilere kavratmak için tarihten alınmış örneklerden faydalanılmalıdır” (MEB, 1948, s. 151).

"Büyük Türk devriminin çeşitli cephelerini öğrencilere açıklamakla beraber onlara Türk devriminin çeşitli cephelerinin ne kadar önemli olduğunu ve Türk ulusunun devrimin muhtelif cephelerde yaptığı her hamle ile nasıl kurtulduğumuzu çocuklara kavratmaktır" (MEB, 1948, s. 144).

"Öğretmen, bireylerin bir yandan kendi yeteneklerine, bir yandan da ulusun iyiliği için en uygun bir işe ve mesleğe sarılmalarını önemini belirtmelidir. İnsanın hangi meslekte olursa olsun işini ulusun faydası için en uygun bir şekilde ve en verimli bir surette yapmasının bir ödev olduğunu telkin etmelidir" (MEB, 1948, s. 144).

Bu açıklamalara dayalı olarak 1948 İlkokul Yurttaşlık Bilgisi Dersi Öğretim Programında, sosyal bilim disiplinlerinden; siyaset bilimi, hukuk, ekonomi ve sosyoloji disiplinine ait birçok konuya yer verildiği tespit edilmiştir.

1961 İlkokul Yurttaşlık Bilgisi Dersi Öğretim Programı. 1961 İlkokul Yurttaşlık Bilgisi Dersi Öğretim Programı, sosyal bilimler yaklaşımının özellikleri kapsamında değerlendirildiğinde, programın tarih, siyaset bilimi, hukuk, sosyoloji, ekonomi disiplinlerine ait konulara yer verdiği söylenilebilir. Programdaki örnek bulgulardan bazıları şunlardır: 
"Tarih dersi, Yurttaşlık Bilgisi dersi ile olan sıkı bağlılığı dikkate almalı, cumhuriyet rejiminin Türk toplum hayatına uygun olduğunu çocuklara anlatırken, eski rejim ile cumhuriyet rejimi arasında karşılaştırmalar yaptırmalıdır” (MEB, 1961, s. 128).

"Yurttaşlık bilgisi dersi daima başka derslerle ilgisi göz önünde bulundurulacaktır. Örneğin cumhuriyet rejiminin başka rejimlere üstünlüğünü, Türk devriminin ayrı ayrı cephelerini öğrencilere kavratmak için tarihten alınmış örneklerden faydalanılmalıdır” (MEB, 1961, s. 149-150).

"İnsanın hangi meslekte olursa olsun işini ulusun faydası için en uygun bir şekilde ve en verimli bir surette yapmasının bir ödev olduğunu telkin etmelidir" (MEB, 1961, s. 149).

1961 İlkokul Yurttaşlık Bilgisi Dersi Öğretim Programında yer alan bu bulgular, programda siyaset bilimi, tarih ve coğrafya disiplinine ait içeriklerin olduğunu göstermektedir. Programda disiplinler arası ilişkilendirmelere sıkça vurgu yapıldı̆̆ 1 tespit edilmiştir. Bununla öğrencinin birden fazla disipline sahip bir konu üzerinde düşünmesini sağlamaya çalışılmıştır.

1968 İlkokul Sosyal Bilgiler Dersi Öğretim Programı 1968 İlkokul Sosyal Bilgiler Dersi Öğretim Programı, sosyal bilimler yaklaşımına göre incelendiğinde, programda yer alan örnek bulgulardan bazıları şunlardır:

"Topluluk halinde yaşamanın bir zaruret olduğunu öğrencilere kavratmak ve onlara, türlü toplumsal çevrelerde ve çeşitli şartlar altında, diğer insanlarla anlayışlı iş birliği kurma ve düzenli bir şekilde beraber yaşama alışkanlığını kazandırmaktır” (MEB, 1968, s. 63).

“Öğrencilere kanun kavramını öğretmek, yurttaş hak ve hürriyetlerine saygı besleme ve devlet otoritesine uyma duygusu kazandırmaktır (MEB, 1968, s. 63).

$\mathrm{Bu}$ bulgulara göre değerlendirildiğinde, toplumsal işbirliği ve topluluk gibi kavramlara değinilmesi sosyoloji disipliniyle ilişkili olduğu söylenebilir. Ayrıca "kanun, hak ve hürriyet, devlet otoritesi" adlı kavramlara da değinilmesi, hukuk disiplinine ait konu içeriğine vurgu yapıldığını göstermektedir. Bu bağlamda 1968 ilkokul sosyal bilgiler dersi öğretim programında, tarih, coğrafya, sosyoloji, ekonomi, hukuk ve siyaset bilimi disiplinlerine ait konulara vurgu yapıldı ğı tespit edilmiştir.

1990 İlkokul Sosyal Bilgiler Dersi Öğretim Programı 1990 İlkokul Sosyal Bilgiler Dersi Öğretim Programı, sosyal bilimler yaklaşımı açısından değerlendirildiğinde, programın disiplinler arası bir yaklaşıma sahip olduğunu söylemek mümkündür. Programda yer alan örnek bulgulardan bazıları şunlardır:

"Demokratik hayat, Türkiye Cumhuriyeti Anayasası, Devlet ve Vatandaş ile Cumhurbaşkanı ve Başbakanın görevleri” (MEB, 1990, s. 334).

“Aile, okul ve toplum hayatı ile yakın çevremiz" (MEB, 1990, s. 334).

1990 İlkokul Sosyal Bilgiler Dersi Öğretim Programı, sosyal bilimler yaklaşımına göre tarih, siyaset bilimi, hukuk, sosyoloji, ekonomi ve coğrafya disiplinleriyle ilişkili konu içeriklerinden meydana geldiği söylenebilir.

1932 Orta Mektep Yurt Bilgisi Dersi Öğretim Programı. 1932 Yurt Bilgisi Dersi Öğretim Programı, sosyal bilimler yaklaşımı bakımından incelendiğinde, içeriğinde yer alan konuların farklı disiplinlerle ilişkili olduğu saptanmıştır. Programda yer alan örnek bulgulardan bazıları şunlardır:

"Demokrasi, cumhuriyet, hürriyet, eşitlik, seçim, Teşkilâtıesasiye, kanunlar, hükümet, Türkiye Büyük Millet Meclisi, vekâletlerin vazifeleri, memurlar, köy ve belediye" (Maarif Vekâleti, 1931, ss. 34-37). 
"Vergiler ve vergi çeşitleri, bankalar, ticaret vergileri, muamele vergisi, iktisat, kapitülasyonlar (Maarif Vekâleti, 1931, s. 38).

1932 Orta Mektep Yurt Bilgisi Dersi Öğretim Programı, sosyal bilim yaklaşımına göre değerlendirildiğinde, siyaset bilimi, hukuk, ekonomi ve sosyoloji disiplinlerine ait konulara yer verildiği söylenebilir.

1938 Orta Mektep Yurt Bilgisi Dersi Öğretim Programı. 1938 Orta Mektep Yurt Bilgisi Dersi Öğretim Programı, sosyal bilimler yaklaşımına göre incelendiğinde, çeşitli disiplinlere ait konu içeriklerinin olduğu söylenebilir. Programda yer alan örnek bulgulardan bazıları şunlardır:

"Yurt bilgisi dersinin konuları, millet, devlet, hükümet teşkilatı, demokrasi, ilk hak ve ilk vazife, hürriyet, Mebusun intihabının kanunen sureti cereyanı” (Kültür Bakanlığı, 1938, ss. 55-57).

1938 Orta Mektep Yurt Bilgisi Dersi Öğretim Programı, sosyal bilim yaklaşımına göre değerlendirildiğinde, tek disiplin anlayışına sahip gibi görülse de içeriğine ait konuların siyaset bilimi, hukuk, ekonomi, sosyoloji disiplinleriyle ilişkili olduğu tespit edilmiştir.

1949 Ortaokul Yurttaşık Bilgisi Dersi Öğretim Programı. 1949 Ortaokul Programında, sosyal bilgiler kapsamında olan yurttaşlık bilgisi dersi öğretim programı, sosyal bilimler yaklaşımı açısından incelenerek buna dayalı olarak şu örnek bulgulara ulaşıldığı söylenebilir:

"Tarih dersinin yurttaşlık bilgisi dersi ile olan bağlılığı dikkate almalı, cumhuriyet rejiminin Türk toplum hayatına uygun olduğunu çocuklara anlatırken; eski rejim ile cumhuriyet rejimi arasında karşılaştırmalar yaptırmalıdır (MEB, 1949, ss. 92-93).

1949 Ortaokul Yurttaşlık Bilgisi Dersi Öğretim Programında, siyaset bilimi, hukuk, sosyoloji disiplinleriyle ilgili konuları içerdiği saptanmıştır. Ayrıca coğrafya, tarih ve yurttaşlık bilgisi dersine ait konular birbiriyle ilişkilendirilmesi için yönlendirmelerde bulunulduğu tespit edilmiştir.

1962 Ortaokul Yurttaşık Bilgisi Dersi Öğretim Programı. 1962 Ortaokul Yurttaşlık Bilgisi Dersi Öğretim Programı, sosyal bilimler yaklaşımının özellikleri kapsamında incelenmiştir. Programda yer alan örnek bulgulardan bazıları şunlardır:

"Tarih dersiyle yurttaşlık bilgisi dersi ile olan sıkı bağlılığı dikkate almalı, cumhuriyet rejiminin Türk toplum hayatına uygun olduğunu çocuklara anlatırken, eski rejim ile cumhuriyet rejimi arasında karşılaştırmalar yaptırmalıdır” (MEB, 1962, s. 108).

$\mathrm{Bu}$ örnek bulgular değerlendirildiğinde, 1962 Ortaokul Yurttaşlık Bilgisi Dersi Öğretim Programının, farklı disiplin alanlarıyla ilişkili olduğu görülmektedir. Özellikle siyaset bilimi, hukuk, sosyoloji ve ekonomi disiplinlerine ait konulara yer verildiği ve tek disiplin anlayışından ziyade konu içi disiplinler arası bir yaklaşıma sahip olduğu tespit edilmiştir.

1970 Ortaokul Yurttaşık Bilgisi Dersi Öğretim Programı. 1970 Ortaokul Yurttaşlık Bilgisi Dersi Öğretim Programında, sosyal bilimler yaklaşımı açısından şu örnek bulgulara ulaşıldığı söylenilebilir:

"Yurttaşlık bilgisi dersinin başka derslerle ilgisi her zaman göz önünde bulundurulacaktır" (MEB, 1968, s. 136). 
"Yurttaşlık bilgisi dersi okulun içinde demokratik bir toplum hayatının kurulmasını teşvik edecek ve topluluğu meydana getiren bireylerin böyle bir toplum hayatının gerektirdiği duyuş, düşünüş ve davranışı kazanmalarına yardım edecektir” (MEB, 1970, s. 133).

$\mathrm{Bu}$ bulgulardan da anlaşıldığı gibi 1970 Ortaokul Yurttaşlık Bilgisi Dersi Öğretim Programının sosyal bilimler yaklaşımına göre daha önceki (1949, 1962) programlarla benzer özelliklere sahip olduğu söylenilebilir. Burada yurttaşlık bilgisi dersinin başka derslerle ilişkilendirmesi sosyal bilimler yaklaşımına uygun olduğu yorumlanabilir. Programda, siyaset bilimi, hukuk, ekonomi, sosyoloji disiplinlerine ait konu içeriğine değinilmiştir. Özellikle tarihi olaylarda geçen coğrafi etmenler kısmı, dersin disiplinler arası bir yaklaşımla ele alındığı söylenebilir.

1985 Ortaokul Vatandaşlık Bilgileri Dersi Öğretim Programı. 1985 Ortaokul Vatandaşlık Bilgisi Dersi Öğretim Programında, sosyal bilimler yaklaşımı açısından şu örnek bulgulara ulaşıldığı söylenilebilir:

"Vatandaşlık bilgileri programında, öğrencilere ferdi toplum içerisinde yaşaması gerektiğini kavratmak ve onlara toplumun çeşitli çevrelerinde anlayışlı işbirliği ve düzenli şekilde birlikte yaşama alışkanlığı kazandırmaktır” (MEB, 1988, s. 207).

Bir meslek sahibi olmanın gerekliliği, sosyal davranış kurallarıyla uyum içinde olma, Demokrasiyi bizzat yaşayan ve uygulayan kişiler, Çanakkale zaferine değinme" (MEB, 1988, ss. 207-209).

Burada yer alan örnek bulgulardan da anlaşıldığg gibi 1985 Ortaokul Vatandaşlık Bilgisi Dersi Öğretim Programı, sosyal bilimler yaklaşımına ait içeriğe temas edildiği söylenebilir. Bu programda siyaset bilimi, tarih, coğrafya, sosyoloji, ekonomi ve hukuk disiplinlerine ait konulara yer verildiği saptanmıştır.

1998 İlköğretim Sosyal Bilgiler Dersi Öğretim Programı 1998 İlköğretim Sosyal Bilgiler Dersi Öğretim Programı, sosyal bilim yaklaşımının özellikleri kapsamında değerlendirildiğinde şu örnek bulgulara ulaşıldığı söylenebilir:

“İlköğretim dördüncü ve beşinci sınıf sosyal bilgiler ders konuları yalnız tarih, coğrafya veya vatandaşlık bilgisi yönünden değil, çok yönlü bir bütün olarak incelenmelidir” (MEB, 1998).

"Ailenin refah ve mutluluğu için sorumluluk ve görev duygusuyla hareket eder" (MEB, 1998, s. 333).

"Aile, okul ve toplum hayatı ile yakın çevremiz" (MEB, 1998, s. 337).

1998 İlköğretim Sosyal Bilgiler Dersi Öğretim Programı, sosyal bilimler yaklaşımına uygun özelliklere sahip olduğu söylenebilir. Örnek bulgulardan da anlaşıldığı gibi siyaset bilimi, hukuk, sosyoloji, ekonomi, tarih ve coğrafya disiplinlerine ait konuları içerdiği saptanmıştır. Ayrıca dersin çok yönlü ve bütün olarak irdelenilmesi gerektiği belirtilmiştir.

2005 İlköğretim Sosyal Bilgiler Dersi Öğretim Programı. 2005 Sosyal Bilgiler Dersi Öğretim Programı, sosyal bilimler yaklaşımına uygun özelliklere sahip olduğu, ayrıca sosyal bilimlere ait konu içeriklerinin en fazla olduğu programdır. Programda yer alan örnek bulgulardan bazıları şunlardır:

"Sosyal bilgiler, bireyin toplumsal varoluşunu gerçekleştirebilmesine yardımcı olması amacıyla; tarih, coğrafya, ekonomi, sosyoloji, antropoloji, psikoloji, felsefe, siyaset bilimi ve hukuk gibi sosyal bilimleri ve vatandaşlık bilgisi konularını yansıtan; öğrenme alanlarının bir ünite ya da tema altında birleştirilmesini içeren; insanın sosyal ve fizikî 
çevresiyle etkileşiminin geçmiş, bugün ve gelecek bağlamında incelendiği; toplu öğretim anlayışından hareketle oluşturulmuş bir ilköğretim dersidir.” (MEB, 2005).

$\mathrm{Bu}$ tanımdan da yola çıkarak bilgi temelinde sosyal bilimler yaklaşımının merkeze alındığını görmek mümkündür. Sosyal bilimlere ait konuların ilköğretim düzeyindeki öğrencilere öğrenme alanları bünyesinde verilmek istendiği söylenebilir. Özellikle öğrenme alanları, birden fazla akademik disiplinin konularını içermektedir. Bununla birlikte öğrenme alanlarında, çeşitli disiplinlere ait konular, tematik bir şekilde birbiriyle ilişkilendirilmiştir. $\mathrm{Bu}$ öğrenme alanları içerisinden, "birey ve toplum" öğrenme alan1; psikoloji, sosyoloji ve antropoloji disiplinleriyle "kültür ve miras" öğrenme alanı, antropoloji, tarih ve sosyoloji disiplinleriyle ilişkilendirme yapılarak verildiği söylenebilir. Kısacası, 2005 sosyal bilgiler dersi öğretim programı, sosyal bilimler yaklaşımının özelliklerinin ağır bastığı bir program olduğu saptanmıştır.

\section{7 İlkokul ve Ortaokul Sosyal Bilgiler Dersi Öğretim Programı. 2017}

İlkokul ve Ortaokul Sosyal Bilgiler Dersi Öğretim Programı, içeriğine bakıldığında disiplinler arası bir program olduğu söylenebilir. Bu bağlamda programda özel amaçlar, bilgi, beceri ve değerlerle birlikte öğrenme alanları bu kapsamda değerlendirilebilir. Programda yer alan örnek bulgulardan bazıları şunlardır:

\footnotetext{
"Sosyal Bilgiler öğrenme alanlarında; tarih, coğrafya, ekonomi, sosyoloji, antropoloji, psikoloji, felsefe, siyaset bilimi ve hukuk gibi sosyal bilimler ile insan hakları, yurttaşlık ve demokrasi konuları bütünleştirilmiş olarak ele alınmaktadır. Konular tarih, coğrafya, insan hakları ve vatandaşlık diye ayrı ayrı değil, disiplinler arası yaklaşımla işlenmelidir” (MEB, 2018, s. 10).
}

Bu açıklamalardan da anlaşıldığı gibi 2017 İlkokul ve Ortaokul Sosyal Bilgiler Dersi Öğretim Programının konuları farklı disiplin alanları ile bütünleştirilerek disiplinler arası bir yaklaşımla oluşturulduğu saptanmıştır. Özellikle programda "sosyal bilimler olarak sosyal bilgiler” anlayışına önem verilmesi gerektiği, öğrencilere, sosyal bilimcilerin (coğrafyacının, tarihçinin vb.) kullandıkları bilimsel yöntemler sezdirilerek öğrenmenin kalıcı olmasına katkı sağlayacağı yorumlanabilir (MEB, 2018).

Öğrenme alanlarına bakıldığında ise birey ve toplum öğrenme alanının içeriği, ben ve biz olma süreci, tarihi ve kültürel faktörler; psikoloji, sosyoloji ve sosyal psikolojiye odaklanmakta; kültür ve miras öğrenme alanı, kültür, toplum, tarihsel konular, dünya gibi kavramlara değinilmesi tarih, antropoloji, coğrafya ve sosyoloji disiplinleriyle ilişkilendirilebilir. İnsanlar, yerler ve çevreler öğrenme alanında yer alan insan yaşamı, çevre, mekân, yakından uzağa, değişim gibi kavramlar coğrafya ve ekonomi gibi disiplinlerin konu içeriğiyle ilgili olduğu söylenebilir. Bilim, teknoloji ve toplum öğrenme alanında, yenilikçi, eleştirel, bilimsel düşünme, teknoloji, toplum gibi konulara temas etmesi, tarih, sosyoloji gibi disiplinlerle ilişkili olduğu yorumlanabilir. Üretim, dağıtım ve tüketim öğrenme alanında geçen kaynaklar, kaynakların sınırlılığı, ekonomik koşullar, meslekler adlı kavramlara değinilmesi ekonomi, coğrafya, sosyoloji gibi disiplinlere temas edildiği söylenebilir. Etkin vatandaşlık öğrenme alanı daha önceki 2005 programında yer alan gruplar, kurumlar ve sosyal örgütler ile güç, yönetim ve toplum öğrenme alanları birleştirilerek yeniden oluşturulmuştur. $\mathrm{Bu}$ öğrenme alanında yer alan toplum, toplumsal sorunlar, grup, kurum, birey ve kültür, sosyal örgüt, demokratik yol adlı kavramlara temas edilmesi sosyoloji, siyaset bilimi ve hukuk disiplinleri çerçevesinde oluştuğu tespit edilmiştir. Küresel bağlantılar öğrenme alanına bakıldığında; bilgi, teknoloji, kültürel, insanlar, fikirler, inançlar, dünya gündemi, iş 
birliği adlı kavramlara değinilmesi bu öğrenme alanının disiplinler arası bir şekilde yapılandırıldığını ortaya koymaktadır (MEB, 2018).

\section{Yansıtıcı Araştırma Olarak Sosyal Bilgiler Öğretimi Yaklaşımına Göre Bulgular}

1924 (1340) Musahabat-ı Ahlakiye ve Malumat-ı Vataniye Dersi Öğretim

Programı. 1924 programının temel felsefesinde daimicilik ve esasicilik akımlarının etkisi hâkim olsa da (Hamarat, 2015), programda yansıtıcı araştırmaya dair açıklamalara rastlamak mümkündür. Örneğin öğrencilere sahip olduğu hakları tanıtarak, sahip olması gereken ahlaki değerlerin ne olduğuna vurgu yapılmıştır. Ahlaki değerleri sadece kazanım olarak ifade etmekten ziyade değerlerin çocuklara kazandırılması üzerinde durulmuştur. Burada değer öğretiminden ve yaparak yaşayarak öğrenmeden söz etmek mümkündür. Programda geçen örnek bulgulardan bazıları şunlardır:

"ilk sınıftan itibaren mektebin umumi hayatına iştirak edebilmesi, yaşlarının idraklerinin derecesine göre kendilerine küçük vazifeler tevdi' olunması, koleksiyonların, sınıf müzesinin, kütüphanenin, mekteb bahçesinin müştereken vücuda getirilmesi, bazı işlerin müştereken yapılması, bazı işlerin müştereken amil idilmesi gibi tedbirler, çocuklarda intizam ve faaliyet, teavün-ü tesanid, şahsi ve müşterek me'suliyet hasri gibi en yüksek ahlaki ve içtimai kabileyetlerin inkişaf ve takviyesine hizmet eder (Maarif Vekâleti, 1924, s. 30).

1924 programında, yansıtıcı araştırma olarak sosyal bilgiler yaklaşımında özellikle değerler açısından (sorumluluk, temizlik, dürüstlük, çalışkanlık vb.) önemli açıklamalara vurgu yapıldığı saptanmıştır. Öğrencinin ilgi ve ihtiyaçları göz önünde bulundurulması ve bizzat olayları yaparak yaşayarak öğrenmesi gerektiğine dair açıklamalar söz konusudur. 1924 programında, yansıtıcı araştırma olarak sosyal bilgiler yaklaşımı açısından bakıldığında, vatandaşlık aktarımı kadar güçlü olmasa da o günün şartları içerisinde yansıtıcı araştırma yaklaşımına ait özellikleri taşıdığını söylemek mümkündür.

1930 Yurt Bilgisi Dersi Öğretim Programı 1930 İlk Mektep Müfredat Programında, öğrencilerde eleştirel bakış açısının geliştirilmesine vurgu yapılmıştır (Tuğluoğlu \& Tunç, 2010). Ayrıca programda öğrencilerin deneyim kazanması adına önce konulara ait bazı kavramların öğretildiği görülmektedir (Gelen \& Beyazıt, 2007). Ayrıca programda, yardımseverlik ve dayanışma, sevgi, temizlik, dürüstlük, sorumluluk gibi değerlere rastlamak mümkündür. Programda geçen örnek bulgulardan bazıları şunlardır:

"Mektep sıralarını kesmek, duvarları çizmek, arkadaşlara karşı haksız bir harekette bulunmak, kırılmasına sebebiyet verilen bir camı ödemek, dershanenin temizliğine ve intizamına dikkat etmek gibi olaylar" (Maarif Vekâleti, 1930, s. 79-80).

"Yurt bilgisi dersinin öğretiminde hiçbir vakit sadece takriri bir ders olarak tedris olunamayacağı gibi bir nevi kıraat dersi olarak da okutulamaz. Bu ders tabiat tetkiki dersi derecesinde müşahedeye, tetkik ve tefekküre istinat eder" (Maarif Vekâleti, 1930, s. 79).

"Mektep hayatına dair bazı meselelerin zaman zaman umumi bir surette müzakere edilmesi de çok faydalı neticeler verir ve gençleri ileride umumi işlerin müzakeresine alıştırır (Maarif Vekâleti, 1930, s. 80).

Bu açıklamalara bakıldığında, öğrenciyi derste olaylara karşı hem düşünme hem de sorgulama becerisinin geliştirilmeye çalışıldığı söylenilebilir. Bunun yanı sıra öğrencide karar verme ve yaratıcı düşünme becerisinin oluşturulmaya çalışıldığı 
yorumlanabilir. Bu bağlamda bu program yansıtıcı araştırma yaklaşımına ait özellikleri taşıdığı söylenebilir.

1948 Yurttaşlık Bilgisi Dersi Öğretim Programı. 1948 İlkokul Yurttaşlık Bilgisi Dersi Öğretim Programı, yansıtıcı araştırma yaklaşımının özellikleri kapsamında incelendiğinde, öğrencinin derste aktif olmasını gerektiren bilgilere yer verildiği saptanmıştır. Programdaki örnek bulgulardan bazıları şunlardır:

"Yurttaşlık bilgisi dersinde konunun iç yüzünü öğrencilere kavratmak için onu en basit ve somut örneklerle canlandırmaya çalışmalıdır. Mesela milletvekili veya belediye seçimi hakkında bir fikir verilirken okulda şu veya bu iş için sınıf adına arkadaşları seçme işinden faydalanmalıdır" (MEB, 1948, s. 145).

"Derste öğretmen öğrenciye kuru kuru bilgi vermek yerine, derste işlenecek konular üzerinde onları düşündürmeli, öğrencilerin anlayacakları ve görüp inceleyecekleri canlı örneklerle o problemlerin manasını kendilerine kavratmalıdır" (MEB, 1948, s. 149).

"Yurttaşlık bilgisi konularını canlandırmak için resimlerden, fotoğraflardan, tablolardan ve afişlerden faydalanmalıdır" (MEB, 1948, s. 151).

$\mathrm{Bu}$ açıklamalara göre öğrencinin bazı olayları daha iyi anlaması için canlandırma yapması, kısaca yaparak yaşayarak öğrenmesine vurgu yapıldığı söylenebilir. Ayrıca sosyal bilgiler dersi açısından önemli olan iyilik, çalışkanlık, dürüstlük, sorumluluk, vatansever, sevgi ve saygı gibi değerlere de vurgu yapıldı̆̆ tespit edilmiştir.

1961 İlkokul Yurttaşlık Bilgisi Dersi Öğretim Programı. 1961 İlkokul Yurttaşlık Bilgisi Dersi Öğretim Programı, yansıtıcı araştırma yaklaşımının özellikleri açısından incelendiğinde, düşünme ve sorgulama becerisine sıkça vurgu yapıldığı, gerçek bir olay etrafında, problem çözme becerisinin ortaya çıkarılmaya çalışıldığı söylenebilir. Programda geçen örnek bulgulardan bazıları şunlardır:

"Yurttaşlık bilgisi ders programında, bu derste öğretmen öğrencilere kupkuru bilgiyi vermekle dersin gayesine varmış olamaz. Derste işlenecek konular üzerinde onları düşündürmelidir. Öğrencilerin anlayacakları ve görüp inceleyecekleri canlı örneklerle o problemin manasını kendilerine kavratmalıdır" (MEB, 1961).

"Yurttaşıı Bilgisi konularına karşı öğrencilerin ilgisini uyandırmaya ve bu konuları canlandırmaya çalışacaktır" (MEB, 1961, s. 151).

"Öğrenci bir yandan da sokağı temiz tutmanın yurttaş bir görev olduğu telkin edilmeli, ayrıca çocuklara sokağın temizliğini bozacak hareketlerde sakınmayı alıştırmalıdır” (MEB, 1961, s. 149).

1961 İlkokul Yurttaşılı Bilgisi Dersi Öğretim Programında, yansıtıcı araştırma yaklaşımına ait özelliklere yer verildiği söylenebilir. Örnek bulgulardan anlaşıldığı gibi düşünme, sorgulama ve muhakeme becerisine sahip bir dersin işlenilmesi gerektiği belirtilmektedir. $\mathrm{Bu}$ açıklamalara dayalı olarak programda, sıkça vurgulanan diğer bir öğe de değerlerdir. Özellikle sorumluluk, sevgi, sayg1, temizlik ve vatanseverlik gibi değerlere temas edildiği saptanmıştır. Program çağdaş değerlere daha çok yakınlaştırılmıştır. Özellikle öğrencinin derste aktif olması adına ders içeriklerinde sıkça üzerinde durulan bir konu olduğu söylenebilir.

1968 İlkokul Sosyal Bilgiler Dersi Öğretim Programı 1968 Sosyal Bilgiler Dersi Öğretim Programı, öğrencinin aktif öğrenme ve kendi yaşam deneyimleri oluşturma adına önemli niteliklere sahip olduğu söylenilebilir. Programda: sorumluluk, 
yardımlaşma, güven, hak, sayg1, sevgi, takdir gibi değerlere vurgu yapıldığı tespit edilmiştir. Programda geçen örnek bulgulardan bazıları şunlardır:

“Toplumda insanların birbiriyle olan ilişkisi yönünden' beraber çalışma, sorumluluk alma, yardımlaşma ve karar verme kurallarını uygulamayı öğrenirler. Kanun ve nizama karşı saygı duyma" (MEB, 1968, s. 64).

"Ünitelerin işlenmesinde 'yakından uzağa' ilkesine uyulmalıdır. Yurttaşlık bilgisi dersinde öğrenciye sadece bilgi vermekle kalınmamalı, verilen bilgi duyguları uygulayabilme gücü kazandırmalıdır" (MEB, 1968, s. 65).

1968 İlkokul Sosyal Bilgiler Dersi Öğretim Programında, öğrencinin derste olaylar üzerinde düşünmesi ve araştırma yapması, olayları canlandırması gibi ifadelere vurgu yapıldığı saptanmıştır. Bu nedenle 1968 İlkokul Sosyal Bilgiler Dersi Öğretim Programı, yansıtıcı araştırma yaklaşımına ait özellikleri içerdiği söylenilebilir.

1990 İlkokul Sosyal Bilgiler Dersi Öğretim Programı. 1990 İlkokul Sosyal Bilgiler Dersi Öğretim Programı, yansıtıcı araştırma yaklaşımı kapsamından incelendiğinde, derste çeşitli öğretim metotlarının kullanılması için talimatlara yer verildiği, dersin sadece soru-cevap veya anlatım yöntemiyle işlenilmemesi gerektiği belirtilmiştir. Programda geçen örnek bulgulardan bazıları şunlardır:

"Dersin işlenişinde sadece soru-cevap ve anlatım yöntemi değil çeşitli metotlara yer verilmelidir. Özellikle aktif öğrenme yöntemleri, araştırma ve incelemeye sevk eden yöntemler kullanılmalıdır. Ayrıca öğretmen ders kitabıyla yetinmemeli farklı kaynakları kullanmalı ve öğrencinin seviyesini göz önünde bulundurulmalıdır” (MEB, 1990, s. 333).

1990 İlkokul Sosyal Bilgiler Dersi Öğretim Programında yer alan açıklamalara bakıldığında, yansıtıcı araştırma yaklaşımına ait özellikleri taşıdığı söylenebilir.

1932 Orta Mektep Yurt Bilgisi Dersi Öğretim Programı. 1932 Orta Mektep Müfredat Programında, sosyal bilgiler kapsamına giren yurt bilgisi dersi, yansitıcı araştırma yaklaşımına göre değerlendirildiğinde, öğrencinin derste nasıl bir görev içerisinde bulunacağına ya da derslerin nasıl işleneceğiyle ilgili herhangi bir açıklamaya rastlanmamıştır. $\mathrm{Bu}$ doğrultuda 1932 Orta Mektep Yurt Bilgisi Dersi Öğretim Programında, yansıtıcı araştırmaya uygun özellikler yer almadığı söylenebilir.

1949 Ortaokul Yurttaşlık Bilgisi Dersi Öğretim Programı. 1949 Ortaokul Yurttaşlık Bilgisi Dersi Öğretim Programında, yansıtıcı araştırma yaklaşımına uygun şu bulguları görmek mümkündür:

“Öğretmen, yurttaşlık bilgisi dersinde öğrenciye kazandıracağı bilgiyi toplumsal yaşamı da içine alacak şekilde olmalı, yaşanmış olayları birer problem olarak ele almalı, bunları öğrencilere teker teker veya gruplar halinde sınıf̧a incelemesine, tartışmasına imkânlar hazırlayarak onlara rastladıkları problemleri çözme alışkanlığı kazandııılmalıdır. Ayrıca problemin çözülmesinde bilimsel yollardan faydalanılmalıdır. Öğrenci konuyu daha iyi anlaması açısından ders dışı etkinlikler, yani gezi ve gözlem yöntemi kullanılarak konu öğrencinin gözü önünde canlandırılmalıdır.” (MEB, 1949, s. 116).

1949 Ortaokul Yurttaşlık Bilgisi Dersi Öğretim Programında, öğrencinin aktif olması için önemli vurgular yapılmıştır. Öğrencinin konular üzerinde düşünmesi ve bunları tarihi süreç içerisinde karşılaştırarak yaratıcı düşünme becerisinin ortaya çıkartılmaya çalışıldığı söylenebilir. Programda, temizlik, yardımlaşma ve takdir gibi değerlere de vurgu yapılmıştır. Kısacası 1949 Ortaokul Yurttaşlık Bilgisi Dersi Öğretim Programının içeriği yansıtıcı araştırma yaklaşımına uygun özelliklere değinilmiştir. 
1962 Ortaokul Yurttaşlık Bilgisi Dersi Öğretim Programı. 1962 Ortaokul Yurttaşlık Bilgisi Dersi Öğretim Programında, yansıtıcı araştırma yaklaşımının şu özelliklerini görmek mümkündür:

"Öğretmen yurttaşlık bilgisi dersinde öğrenciye kazandıracağı bilgiyi toplumsal yaşamı da
içine alacak şekilde olmalı, yaşanmış olayları birer problem olarak ele almalı, bunları
öğrencilere teker teker veya gruplar halinde sınıf̧̧a incelemesine, tartışmasına imkânlar
hazırlayarak onlara rastladıkları problemleri çözme alışkanlığı kazandırılmalıdır. Ayrıca
problemin çözülmesinde bilimsel yollardan faydalanılmalıdı»” (MEB, 1962, s. 135).

1962 Ortaokul Yurttaşlık Bilgisi Dersi Öğretim Programı, yansıtıcı araştırma yaklaşımı kapsamında değerlendirildiğinde, toplumsal bir olay üzerinde meydana gelen bir problemin bilimsel kurallara uygun bir şekilde çözüme kavuşturulması için direktiflerde bulunulduğu söylenilebilir. Programda, sevgi, sayg1, muhabbet ve yardımlaşma adlı değerlere de vurgu yapıldığı saptanmıştır.

1970 Ortaokul Yurttaşık Bilgisi Dersi Öğretim Programı. 1970 Ortaokul Yurttaşlık Bilgisi Dersi Öğretim Programında, yansıtıcı araştırma yaklaşımının özelliklerine ulaşılmıştır. Buna uygun örnek bulgulardan bazıları şunlardır:

“Öğretmen yurttaşlık bilgisi dersinde öğrenciye kazandıracağı bilgiyi toplumsal yaşamı da içine alacak şekilde olmalı, yaşanmış olayları birer problem olarak ele almalı, bunları öğrencilere teker teker veya gruplar halinde sınıf̧a incelemesine, tartışmasına imkânlar hazırlayarak onlara rastladıkları problemleri çözme alışkanlığı kazandırılmalıdır. Ayrıca problemin çözülmesinde bilimsel yollardan faydalanılmalıdır.” (MEB, 1970, s. 135).

$\mathrm{Bu}$ açıklamalar değerlendirildiğinde, 1970 Ortaokul Yurttaşlık Bilgisi Dersi Öğretim Programında, toplumsal bir olay üzerinde meydana gelen bir problemin bilimsel kurallara uygun bir şekilde çözüme kavuşturulması istendiği söylenilebilir. Bunun sonucunda, öğrenciyi derste aktif tutan ve konular etrafinda öğrenciye deneyim kazandırmak amacıyla bir problem etrafında düşünen, sorgulayan ve bunun için çözüm üreten bir öğretim anlayışı olduğu görülmektedir.

1985 Ortaokul Vatandaşlık Bilgileri Dersi Öğretim Programı. 1985 Ortaokul Vatandaşlık Bilgisi Dersi Öğretim Programı, yansıtıcı araştırma yaklaşımının özellikleri açısından değerlendirildiğinde, şu bulgulara ulaşılmıştır:

"Bugünü daha iyi anlamak için geçmişin sosyal, ekonomik ve siyasal olayların sebeplerini ve sonuçları üzerinde günümüzde kıyaslama yaparak düşünme, araştırma ve muhakeme etme yeteneğini gerçekleştirmektir" (MEB, 1988, s. 208).

Burada yer alan açıklamalara dayalı olarak 1985 Ortaokul Vatandaşlık Bilgisi Dersi Öğretim Programında, yansıtıcı araştırma yaklaşımına ait içeriğe az da olsa yer verildiği saptanmıştır. Öğrencinin olaylar üzerinde düşünmesi ve olayları sorgulayarak karşılaştırma yapmasına vurgu yapıldığ s söylenebilir. $\mathrm{Bu}$ programda, öğrencinin yaparak yaşayarak öğrenmesini sağlayacak bilgilere yer verildiği, ayrıca düşünme ve sorgulama becerisine ait açıklamalara da değinilmiştir.

1998 İlköğretim Sosyal Bilgiler Dersi Öğretim Programı 1998 İlköğretim Sosyal Bilgiler Dersi Öğretim Programı, yansıtıcı araştırma yaklaşımının özellikleri açısından irdelenmiştir. Programda geçen örnek bulgulardan bazıları şunlardır:

"Sosyal bilgiler dersinde çevre özellikleri göz önünde bulundurulmuş, öğretmen ders işlenişinde yakında uzağa ilkesine göre hareket edilmesi gerektiği belirtilmiştir. Dersin işlenişinde sadece soru-cevap ve anlatım yöntemi değil çeşitli metotlara yer verilmelidir. Özellikle aktif öğrenme yöntemleri, araştırma ve incelemeye sevk eden yöntemler 
kullanılmalıdır. Ayrıca öğretmen ders kitabıyla yetinmemeli farklı kaynakları kullanmalı ve öğrencinin seviyesini göz önünde bulundurulmalıdır” (MEB, 1998, s. 332-333).

Örnek bulgudan da anlaşıldı̆̆ı gibi 1998 İlköğretim Sosyal Bilgiler Dersi Öğretim Programında, dersin işleniş yönteminden, aktif öğrenme yöntemleri, sorucevap, araştırma ve inceleme yöntemlerine temas edildiği söylenilebilir. Ayrıca programda, yardımlaşma, sorumluluk, hak, saygı, hoşgörü gibi değerlere vurgu yapılmıştır. Bu bağlamda program, yansıtıcı araştırma yaklaşımının niteliklerine sahip olduğu yorumlanabilir.

\section{5 İlköğretim Sosyal Bilgiler Dersi Öğretim Programı. 2005 Sosyal} Bilgiler Dersi Öğretim Programı, yapılandırmacı eğitim anlayışına göre şekillendirilmiş bir programdır. Program, eleştirel ve yaratıcı olarak doğru karar veren nitelikli insan yetiştirmeyi hedefler. Bu bağlamda, 2005 sosyal bilgiler dersi öğretim programı, yansıtıcı araştırma yaklaşımına göre değerlendirildiğinde şu örnek bulgulara ulaşılmıştır:

"Bilginin kazanılmasında, kullanılmasında ve donanımlı insan gücünün yetiştirilmesinde de en önemli görev eğitim sistemimize düşmektedir. Tüm ihtiyaçlar doğrultusunda dünyada yaşanan gelişmelere paralel olarak, öğretim programlarında yeni yaklaşımlar dikkat çeker duruma gelmiştir. $\mathrm{Bu}$ nedenle program, tümüyle davranışçı yaklaşımlardan öte, bilginin taşıdığı değeri ve bireyin var olan deneyimlerini dikkate alarak, yaşama etkin katılımını, doğru karar vermesini, sorun çözmesini destekleyici ve geliştirici bir yaklaşım doğrultusunda yapılandırmayı önemseyen bir gelişim göstermektedir. Bu yaklaşımla öğrenci merkezli, dolayısıyla etkinlik merkezli, sosyal bilgiler açısından, bilgi ve beceriyi dengeleyen, öğrencinin kendi yaşantılarını ve bireysel farklılıklarını dikkate alarak çevreyle etkileşimine olanak sağlayan yeni bir anlayış yaşama geçirilmeye çalışılmaktadır (MEB, 2008, s, 4).

Bilindiği gibi bilgi temelli bir program anlayışı günümüzde önemini yitirmiştir. Bunun yerine bilgi ve beceriyi birlikte kullanarak öğrendiklerini kendi yaşamına yansıtan bir öğretim anlayışı yaygınlaştığı söylenilebilir. Bu bağlamda öğrenci, yaşama etkin katılarak doğru karar vermesini ve sorunlara çözüm üretmesini destekleyen bir gelişim yaşanmıştır. Sosyal bilgiler dersi, demokratik değerleri benimsemiş vatandaşlar olarak öğrencilerin içinde yaşadığı topluma uyum sağlamalarını ve öğrencilere bu bilgi birikimini yaşamda etkin kullanmayı amaçlamaktadır. Bu nedenle 2005 Sosyal Bilgiler Dersi Öğretim Programı, bilginin değerini ve bireyin kendi deneyimleri göz önünde bulundurarak yaşama etkin katılan ve toplumsal sorunlara çözüm üreterek etkili kararlar almasını sağlayan bir program olduğu saptanmıştır.

2017 İlkokul ve Ortaokul Sosyal Bilgiler Dersi Öğretim Programı. 2017 İlkokul ve Ortaokul Sosyal Bilgiler Dersi Öğretim Programının yansıtıcı araştırma yaklaşımına ait özellikler taşıdığını söylemek mümkündür. Programda geçen örnek bulgulardan bazıları şunlardır:

\footnotetext{
"Yansıtıcı düşünme olarak sosyal bilgiler anlayışlarına önem verilerek okulun içindeki ve dışındaki olaylardan yararlanılarak öğrenciler sık sık gerçek hayat problemleri ve çelişkili durumlarla karşılaştırılmalı ve karşılaştıkları sosyal problemler üzerine yansıtıcı düşünmeleri sağlanmalıdır” (MEB, 2018, s. 10).

"Kazanımlarla ilgili güncel ve tartışmalı konular, farklı tartışma teknikleri kullanılarak problem çözme, eleştirel düşünme, kanıt kullanma, karar verme ve araştırma becerileriyle ilişkilendirilerek sınıfa taşınabilir" (MEB, 2018, s. 10).

"Dijital teknolojideki gelişmelere bağlı olarak vatandaşlık hak ve sorumluluklarıyla ilgili yeni durumlar (dijital vatandaşlık, e-Devlet, sanal ticaret, sosyal medya vb.) ve birtakım
} 
sorunlar (dijital bölünmüşlük, kimlik hırsızlığı, kişisel bilginin gizliliği, siber dolandırıcılık, siber zorbalık vb.) ortaya çıkmıştır. Öğrencilerin dijital vatandaşlık yeterliliklerini geliştirmek amacıyla konuyla ilgili ders içi ve ders dışı etkinliklere yer verilmelidir (MEB, 2018, s. 10).

$\mathrm{Bu}$ örnek açıklamalardan da anlaşıldığı gibi program yansıtıcı araştırma yaklaşımının niteliklerini taşıdığı söylenebilir. Özellikle 2017 Sosyal Bilgiler Dersi Öğretim Programının, bilim ve teknolojinin gelişim süreci ve toplumsal yaşam üzerindeki etkisini kavrama, eleştirel düşünme, problem çözme, yansıtıcı düşünme; sorunlara çözüm bulma, karar verme becerisi, bireysel farklılıkları göz önünde bulundurma, katılımcı olma, iletişim becerilerini geliştirme, bilgiye ulaşma ve bilgiyi kullanma, dijital okuryazarlık gibi kavramlara vurgu yaptığı tespit edilmiştir. Ayrıca programın temel felsefesi hak ve sorumluluklarını bilen etkin ve üretken vatandaşlar yetiştirmeyi hedeflediği söylenebilir.

\section{Sonuç ve Tartışma}

Cumhuriyetten günümüze sosyal bilgiler dersi öğretim programlarının sosyal bilgiler öğretim yaklaşımlarına göre sonuçları genel olarak değerlendirildiğinde, ilkokul 1924, 1930, 1948, 1961, 1968, 1990 programlar1; 1932, 1938, 1949, 1962, 1970, 1985 ortaokul programları, 1998, 2005 ilköğretim sosyal bilgiler dersi öğretim programları ve 2017 ilkokul ve ortaokul programının vatandaşlık aktarımının genel özelliklerini taşıdığını söylemek mümkündür. Özellikle vatandaşlık aktarımı açısından programlarda vurgulanan temalar, iyi vatandaş yetiştirme, cumhuriyet ideolojisine uygun vatandaş, milletine ve devletine karşı görev ve sorumluluk bilincine sahip bireyler yetiştirmektir. Ayrıca eski tarihi kişiliklerin hayatları, ülkesi için canla başla mücadele eden ve bunu yaşamında bir ülkü ve inanç haline getiren; üretken, hak ve sorumluluklarını bilen demokrasinin gelişmesine katkı sağlayan insanlar yetiştirmeyi hedeflediği söylenebilir. Programlara göre öğrenci vatandaşlık aktarımında, bir yandan temel vatandaşlık becerilerini kazanmış; bir yandan da kültürel değerlerin taşıyıcısı olmuştur.

Alan yazına baktığımızda, Sözer'in (1998), sosyal bilgiler dersini, temel kültür öğelerini içeren bir ders olarak göstermesini, araştırma sonuçlarını destekler yönde olduğunu söylemek mümkündür. $\mathrm{Bu}$ bağlamda öğrencilerin, ulusal kimliğin oluşmasında kültür öğelerinin ne kadar önemli olduğunu fark etmeleri sağlanır. Bu sonuçları destekler yönde Akyüz (2012) de, cumhuriyetle birlikte eğitim nihai amacının, dönemin değerlerine bağlı insan tipi oluşturma hedefi taşıdığını söylemiştir. Keskin ve Keskin (2013) de araştırmalarında, Cumhuriyetin ilanından günümüze sosyal bilgiler dersinin çocuklara milli bilinç aşılamada bir araç olarak düşünüldüğü sonucunu ortaya koymuştur. Ayrıca alan yazında sosyal bilgiler dersi için "demokratik süreci geliştirecek etkili vatandaşlar yetiştirmek, yeni neslin toplumsallaşması ile beraber toplumun kültürel değerlerini devam ettirmek için geçmişi öğrenmek ve geçmişle gurur duymak, sorumluluk almak, uygun davranışlar sergilemek, otoriteye bağlı olmak, genç kuşakların gelenek ve göreneklerini benimsemesi” hedeflerinin gösterilmesi (Doğanay, 2005; Deveci, 2013; Tay, 2013), araştırmanın sonuçlarını destekler mahiyettedir.

1924 İlk Mektep Müfredat Program1, yeni kurulan cumhuriyetin temel ideolojisine uygun nitelikli insan yetiştirmeyi amaç edinmiştir. Yani cumhuriyet döneminin ideal vatandaşı, devleti ve milleti için mücadele eden ülkesinin kalkınması için çaba sarf eden, cumhuriyet ve demokrasiyi kavramış sorumluluk sahibi bir 
vatandaşlık vurgusu yapılmıştır. Keskin (2002) de araştırmasında, ilk mektep müfredat programının, cumhuriyet ideolojisine uygun nitelikli insan yetiştirmeyi amaç edindiğine değinmiştir. Ayrıca Çelik (2008), cumhuriyetin gerektirdiği insan modelinin oluşturulmasında 1924 ve 1926 ilk mektepler müfredat programlarındaki değişikliklerle cumhuriyet vatandaşının sahip olması gereken bilgi, beceri ve değerlerin çerçevesi çizildiğini belirtmiştir.

Sosyal bilgiler dersi öğretim programları, sosyal bilimler olarak sosyal bilgiler öğretim yaklaşımı kapsamında değerlendirildiğinde, ilkokul 1924, 1930, 1948, 1961, 1968, 1990 programları ile 1932, 1938, 1949, 1962, 1970, 1985 ortaokul programları, sosyal bilim disiplinlerinden siyaset bilimi, hukuk, ekonomi ve sosyoloji disiplinlerine ait konu içeriklerine değinildiği saptanmıştır. Ayrıca sosyal bilgiler dersi kapsamına giren tarih, coğrafya ve yurttaşlık bilgisi dersleri birbirleriyle ilişkilendirilerek 1962 yılında toplum ve ülke incelemeleri adıyla oluşturulmuştur. Fakat 1968 yılına gelindiğinde ABD'deki yeni sosyal bilgiler hareketinin de etkisiyle Türkiye'de ilkokul kademesinde sosyal bilgiler ismiyle yeni bir dersin yapılandırıldı̆̆ı görülmektedir (Keskin, 2002; Sönmez, 2005; Erden, Tarihsiz; Öztürk, 2010). 1998 ve 2005 sosyal bilgiler dersi öğretim programları konu ve ünite yapılanması farklı disiplinlerden oluştuğu söylenebilir. $\mathrm{Bu}$ iki programda konular arası disiplinlerin birleştirme ve bütünleştirmesine önem verildiği saptanmıştır. Bu bulgulara dayalı olarak sosyal bilgiler ile sosyal bilimler arasında önemli bir ilişki olduğu, öğrenciler için hazırlanan bilgilerin sosyal bilim disiplinlerinden yararlandığı belirtilmektedir (Safran, 2010). Bu bağlamda alan yazında 2005 Sosyal Bilgiler Dersi Öğretim Programının içeriğinin, önceden tarih, coğrafya ve vatandaşlık bilgisi olarak anlaş1lırken yeni programda, ekonomi, sosyoloji, antropoloji, psikoloji, felsefe, siyaset bilimi ve hukuk gibi sosyal bilim disiplinlerinden meydana geldiği yönündeki çalışmalar (Bilgili, 2006; Safran, 2010; Sönmez, 2005), araştırmanın sonuçlarını destekler niteliktedir. Ayrıca 2017 İlkokul ve Ortaokul Sosyal Bilgiler Dersi Öğretim Programı, bireyin yaşadığı topluma ve ülkesine, toprağına samimi bir hisle bağlanacak bilim ve teknolojiyi etkin şekilde kullanarak gerekli teknik bilgi, birikim, beceri ve yeterliliklere sahip kuşaklar yetiştirmeyi hedefleyerek güncellenmiştir. Bu nedenle program, farklı disiplinlerin bir arada olduğu ama nihayetin sadece bu disiplinlerin toplamından ibaret olmadığı, kendi niteliklerini taşıyan bir "bütün”e sahip ve aynı zamanda disiplinler arası etkileşimin açık olduğu bir yaklaşımla ele alındığını söylemek mümkündür (MEB, 2018).

Sosyal bilimler olarak sosyal bilgiler öğretim yaklaşımı açısından bakıldığında, Gökdemir'e (2013) göre sosyal bilgiler dersi öğretim programı kapsamında yer alan 1924, 1926, 1930, 1936, 1948 yurt bilgisi dersinde, hukuk disiplinine ait konulara ulaşılması bu çalışmanın sonuçlarını destekler niteliktedir. 1962 Ortaokul Yurttaşlık Bilgisi Dersi Programı ile 1968 İlkokul Sosyal Bilgiler Dersi Öğretim Programının disiplinler arası bir desene sahip olduğunu gösteren çalışmalar da (Keskin, 2002; Yaman, 1999; Turgut, 1992) araştırma sonuçları ile benzer niteliktedir, diyebiliriz.

Sosyal bilgiler dersi öğretim programları, yansıtıcı araştırma olarak sosyal bilgiler öğretim yaklaşımı açısından değerlendirildiğinde ise, 1924, 1938, 1948, 1961, 1968 ve 1990 ilkokul programları ile 1949, 1962, 1968, 1985 ortaokul programlarıyla birlikte 1998 ve 2005 ilköğretim sosyal bilgiler dersi öğretim programları ve 2017 İlkokul ve Ortaokul Sosyal Bilgiler Programında, yansıtıcı araştırmanın özelliklerini 
görmek mümkündür. 1932 ve 1938 orta mektep yurt bilgisi dersi öğretim programlarına baktığımızda ise yansıtıcı araştırmanın özelliklerine yer verilmediği görülmüştür.

Araştırmanın bu sonuçları göz önüne alındığında, Cumhuriyet döneminde John Dewey gibi yabancı eğitim uzmanlarının hazırladıkları raporların, dönemin eğitim programları üzerinde önemli etkiler bıraktığı söylenebilir. Daha sonraki dönemde 1960 ve 1970'li yıllarda meydana gelen gelişmeler ve değişmeler neticesinde, öğrenmeöğretme anlayışındaki yeniliklerin sosyal bilgiler dersine de yansıdığı görülmektedir. $\mathrm{Bu}$ doğrultuda tümdengelim yaklaşımı yerine tümevarım, anlatım yöntemi yerine araştırma yöntemi konulmuş, böylece derslerde aktif öğrenme uygulanmaya başlamıştır (Bilgili, 2006). Bilindiği üzere 2005 sosyal bilgiler öğretim programı, yansıtıcı araştırma yaklaşımının özellikleri olan "karar verme becerisi, problem çözme, etkin katılım, bireysel farklılıkları dikkate alma" gibi öğelere daha fazla vurgu yapmaktadır. Aykaç ve Başar'a (2005) da, 2005 programının, öğrencilerin öğretim sürecine etkinlikler yolu ile aktif olarak katılmasını ve araştırmaya yönlendirmeyi hedeflediğini belirterek bu çalışmanın sonuçlarıyla benzer yönde ifadeler kullanmıştır. Doğanay (2008) da, 2005 programının çağdaş sosyal bilgiler dersi kavramının genel özelliklerini yansıttığını ve programın içeriğinin disiplinler arası bir yaklaşımla ele alındığını vurgulamıştır. Ayrıca 2017 programında (MEB, 2018), “okulun içindeki ve dışındaki olaylardan yararlanılarak öğrencilerin sik sık gerçek hayat problemleri ve çeliş̧ili durumlarla karşılaştırılarak, sosyal problemler üzerine yansıtıcı düşünmelerinin sağlanması" hususu üzerinde durulduğu görülmektedir.

$\mathrm{Bu}$ araştırmadan elde edilen sonuçlara dayalı olarak öncelikle, vatandaşlık aktarımı olarak sosyal bilgiler öğretim yaklaşımının etkilerinin, programlarda değişen iyi insan iyi vatandaş kavramları kapsamında araştırılması önerilebilir. Ayrıca vatandaşlık aktarımının ders kitaplarındaki yansımalarına bakılması, öğretim yaklaşımını daha doğru anlamlandırmak adına yararlı olacaktır. Bunun yanı sıra diğer sosyal bilgiler öğretim yaklaşımları açısından da ders kitaplarındaki uygulanışına bakılabilir. Özellikle sosyal bilimler disiplinlerinin programlardaki yansımalarını incelemek, sosyal bilgilerin muhtevasını keşfetmek adına yararlı olacaktır. Ayrıca yansıtıcı araştırma olarak sosyal bilgiler öğretim yaklaşımının özellikleri dönemin ders kitaplarıyla karşılaştırmalı olarak incelenebilir. 


\section{Summary}

Purpose and Significance: Technological, economical and societal improvements globally have made it necessary to bring several innovations to the field of education. All these innovations have led the teaching programs being applied especially in schools to renew themselves. Thus, the social studies teaching programs in Turkey have been exposed to innovations, updates and amendments at times from the beginning. In this way, it is seen that the research studies on all the social studies programs from the foundation of the republic to nowadays in Turkey have generally focused on the structure, the content and the current state of the programs (Ambarl1, 2010; Keskin, 2002; Koyuncu, 2015; Nalçac1, 2001; Prinçdane, 1997; Yeşil, 1996; Yıldız, 2008). It is understood from the literature review that the programs have never been analyzed in terms of the three teaching approaches of the social studies including (a) teaching social studies as citizenship transmission, (b) teaching social studies as social science and (c) teaching social studies as reflective study. Therefore, the aim of this study is to reveal what kind of progress have been followed in the social studies programs according to the social studies teaching approaches starting from the foundation of the republic to today.

Method: The historic method, which is one of the scanning models, was used in this research since the social studies teaching programs were analyzed from the foundation of the republic to nowadays. First of all, the literature research related to the research problem was carried out because the historic method was used in the study. As a result of this, all the primary $(1924,1930,1938,1948,1961,19681990,2017)$ and the secondary (1932, 1938, 1949, 1962, 1970, 1985, 1998, 2005, 2017) school social studies programs were collected by searching the Board of Education and Discipline and the National library. In addition to these documents, the master thesis and the doctorate dissertations having prepared in the field of social studies were scanned from the Higher Education Institution, Electronic Thesis Archive. Besides, the previous research studies and articles related to the subject were analyzed thanks to libraries and internet. The data collected by the literature review were analyzed according to the descriptive analysis technique. After all the documents had been brought together, the analysis process was started and the criteria were determined with the help of two field experts other than the researcher. At last, the data analysis process was completed successfully.

Results: When the social studies teaching programs were analyzed from the foundation of the republic to nowadays in terms of teaching social studies as citizenship transmission, it is possible to say that the primary school programs in 1924, 1930, 1948, 1961, 1968, 1990 and 2017 years and the secondary school programs in 1932, 1938, 1949, 1962, 1970, 1985, 1998, 2005 and 2017 years have the general properties of citizenship transmission. The themes emphasized in the programs, especially in terms of citizenship transmission, include bringing up a good citizen, a citizen adopting the republic ideology, the duty and responsibility for the homeland, the lives of old famous people, bringing up citizens who can struggle for his nation and have a strong patriotism and citizen who know their rights and responsibilities and contribute to improving democracy. As is known to all, in the citizenship transmission, students are supposed to 
gain the basic citizenship skills and be carriers of the cultural values. Accordingly, students are supposed to notice the importance of the cultural elements in creating a national identity.

When the programs were analyzed in terms of the social science approach, it was found out that the primary school programs in 1924, 1930, 1948, 1961, 1968 and 1990 years and the secondary school programs in 1932, 1938, 1949, 1962, 1970 and 1985 years addressed the subjects belonging to politics, law, economy and sociology disciplines. In addition, it can be said that history, geography and citizenship courses in the scope of the social studies were associated with each other. It was seen that 1998, 2005 and 2017 social studies teaching programs consisted of the disciplines configured with different subjects and units and that combining and integrating the inter-thematic disciplines in these two programs were really important

When the programs were analyzed in terms of the reflective research approach, it was found out that the primary school programs in 1924, 1938, 1948, 1961, 1968, 1990 and 2017 years and the secondary school programs in 1949, 1962, 1970, 1985, 1998, 2005 and 2017 years had the properties of reflective research. There were no properties of reflective research in the secondary school programs in 1932 and 1938 and also there were no any statements on teaching citizenship course in the scope of the social studies in these programs.

Discussion and Conclusions: The school program that was firstly put into effect in 1924 aimed to bring up eligible people for the basic ideology of the republic and it stressed that the ideal citizen for the republic era was a responsible person who struggles for his nation and his country's reconstruction, comprehends the importance of the republic and democracy. Keskin (2002) stated that the first-developed school program aimed to bring up a good individual adopting the republic ideology. In addition, according to Çelik, the framework of the knowledge, skills and values that a republic citizen has to have was drawn thanks to the amendments in the programs in 1924 and 1926 years and it showed similarities with the present study. In terms of the social science approach, Gökdemir (2013) found out that the 1924, 1926, 1930, 1936, 1948 citizenship courses in the scope of the social studies had subjects belonging to law discipline and reached similar results with the present study. The fact that the 1962 and 1968 programs had an interdisciplinary design was determined with the studies by Keskin (2002), Yaman (1999) and Turgut (1992). Also, 1998, 2005 and 2017 programs were configured with an interdisciplinary design. Especially the 2005 program was created in an interdisciplinary way in the framework of the themes and the learning fields of NCSS. The 2005 program focused on the reflective research approach. Doğanay (2008) revealed that the 2005 program reflected the general properties of the contemporary social studies concept and that the content of the program was created with an interdisciplinary design. Besides, Aykaç and Başar (2005) pointed out that the 2005 program aimed to get students to participate in teaching process by the activities and to lead them to do research. 


\section{Kaynakça}

Akhan, N. E., \& Şimşek, Ç. Ö. (2015). Okul öncesi öğretmen adaylarının sosyal bilgiler lisans programı üzerine düşünceleri. Eğitimde Kuram ve Uygulama, 11(2), 551588 .

Akkuş, Z. (2002). İlköğretim okullarında sosyal bilgiler derslerinde Osmanlı kültür ve uygarlı̆̆ konusunun ögretimi (Yayımlanmamış Yüksek Lisans Tezi). Atatürk Üniversitesi, Erzurum.

Akyüz, Y. (2012). Türk eğitim tarihi. Ankara: Pegem A Yayıncılık.

Ambarl1, A. (2010). Türkiye'de cumhuriyetten günümüze sosyal bilgiler programlarl (değişiklikler, düzenlemeler, güncellemeler) (Yayımlanmamış Yüksek Lisans Tezi). Selçuk Üniversitesi, Konya.

Arslan, M. (1999). Cumhuriyet dönemi ilköğretim programları ve belli başlı özellikleri. Milli Eğitim Dergisi, 144. http://dhgm.meb.gov.tr/yayimlar/dergiler/Milli_Egitim_Dergisi/144/arslan.htm

Aykaç, N., \& Başar, E. (2005). İlköğretim sosyal bilgiler dersi eğitim programının değerlendirilmesi. Eğitimde Yansımalar: VIII Yeni İköğretim Programlarını Değerlendirme Sempozyumu Bildiriler Kitabı içinde (ss. 343-361). Ankara: Sim Matbaas1.

Barr, R. D., Barth, J. L., \& Shermis, S. S. (1978). The nature of social studies. California: ETC Publications.

Barth, J. L., \& Demirtaş, A. (1997). İlköğretim sosyal bilgiler öğretimi (kaynak üniteler). Ankara: YÖK / Dünya Bankası Yay.

Bayram, T. (2013). Sosyal bilgiler öğretiminin dünü bugünü ve yarını. R. Turan ve K. Ulusoy (Ed.). Sosyal bilgilerin temelleri içinde (ss. 1-17). Ankara: Pegem A Yayınları.

Berk, F. (2008). Eski ve yeni ilköğretim sosyal bilgiler dersi ögretim programlarl ve ders kitaplarında tarih konularının karşılaştırılması (Yayımlanmamış Yüksek Lisans Tezi). Çukurova Üniversitesi, Adana.

Bilgili, A. S. (2006). Geçmişten günümüze sosyal bilimler ve sosyal bilgiler. İ. H. Demircioğlu. (Ed.). Sosyal bilgilerin temelleri içinde (ss. 3-56). Ankara: Hegem Yayınları.

Büyüköztürk, Ş., Çakmak, E. K., Akgün, Ö. E., Karadeniz, Ş., \& Demirel, F. (2014). Bilimsel araştırma yöntemleri. Ankara: Pegem Akademi.

Çelenk, S., Neşe, T., \& Nurdan, K. (2000). Illköğretim programları ve gelişmeler. Ankara Nobel Yayıncılık

Çelik, H. (2008). Cumhuriyet dönemi vatandaşlık eğitiminde önemli adımlar. Sakarya Üniversitesi Fen Edebiyat Fakültesi Dergisi, 10(1), 359-369.

Çoban, O., \& Akşit, İ. (2018). 2005 ve 2017 sosyal bilgiler öğretim programlarının öğrenme alanı, kazanım, kavram, değer ve beceri boyutları açısından karş1laştırılması. Journal of History Culture and Art Research, 7(1), 479-505. doi:http://dx.doi.org/10.7596/taksad.v7i1.1395

Deveci, H. (2013). Türk eğitim tarihinde sosyal bilgiler. R. Turan ve K. Ulusoy (Ed.). Sosyal bilgilerin temelleri içinde (ss. 19-35). Ankara: Pegem A Yayınları. 
Doğanay, A. (2005). Sosyal bilgiler öğretimi. C. Öztürk ve D. Dilek (Ed.). Hayat bilgisi ve sosyal bilgiler ögretimi içinde (ss. 15-46). Ankara: Pegem A Yayıncılık.

Doğanay, A. (2008). Çağdaş sosyal bilgiler anlayışı 1şığında yeni sosyal bilgiler programının değerlendirilmesi. Çukurova Üniversitesi Sosyal Bilimler Enstitüsü Dergisi, 17(2), 77-96.

Doğanay, A., \& Sarı, M. (2004). Sosyal bilgiler ve sınıf öğretmenleriyle sosyal bilgiler öğretmen adaylarının sosyal bilgilerin doğasına ilişkin yaklaşımlarının değerlendirilmesi. İçinde, I. Sosyal Bilimler Eğitimi Kongresi Tebliğler Kitabı (ss. 153-165). Ankara: MEB Yayınları.

Duman, R. (2011). Demokrat parti döneminde (1950-1960) sosyal bilgiler eğitimi (Yayımlanmamış Yüksek Lisans Tezi). Dokuz Eylül Üniversitesi, İzmir.

Ediger, M. (1988). Social studies curriculum in the elementary school. 2th. Edition. Simpson Publishing Company.

Ercan, M. (2007). Cumhuriyet döneminde ilköğretim sosyal bilgiler programlarındaki sanat konularının yeterliliği (Yayımlanmamış Yüksek Lisans Tezi). Fırat Üniversitesi, Elazığ.

Erden, M. (Tarihsiz). Sosyal bilgiler ögrretimi. İstanbul: Alkım Yayınları

Gelen, İ., \& Beyazıt, N. (2007). Eski ve yeni ilköğretim programları ile ilgili çeşitli görüşlerin karşılaştırılması. Kuram ve Uygulamada Eğitim Yönetimi, 51, 457-476.

Gökdemir, A. (2013). 1924' den günümüze ilköğretim sosyal bilgiler programlarındaki hukuk konularının incelenmesi (Yayımlanmamış Yüksek Lisans Tezi). Niğde Üniversitesi, Niğde.

Hamarat, E. (2015). Sosyal bilgilerin felsefesi. C. Dönmez ve K. Yazıcı (Ed.). Sosyal bilgiler ögrretimi içinde (ss. 24-45). Ankara: Pegem A Yayıncılık.

İnan, S. (2014). Sosyal bilgiler eğitimi: nedir? ne zaman ve neden-tanımlar, tarihi kökleri ve açıklamalar. S. İnan (Ed.). Sosyal bilgiler eğitimine giriş içinde (ss. 121). Ankara: Anı Yayıncılık.

Kaptan, S. (1998). Bilimsel araştırma ve istatistik teknikleri. Ankara: Özkan Matbaacilik.

Karasar, N. (2006). Bilimsel araştırma yöntemi. Ankara. Nobel Yayın Dağıtım.

Kaymakçı, S., \& Ata, B. (2012). Sosyal bilgiler öğretmenlerinin sosyal bilgilerin doğasıyla ilgili görüşleri. Journal of Social Studies Education Research, 3(1), 3564.

Kaz, V. (2013). Cumhuriyetten günümüze ilköğretim 1. kademe sosyal bilgiler programlarının Türk devrimine göre değerlendirilmesi (Yayımlanmamış Yüksek Lisans Tezi). Adnan Menderes Üniversitesi, Aydın.

Keskin, Y. (2002). Türkiye'de II. Meşrutiyetten günümüze kadar uygulanmış olan sosyal bilgiler öğretim programlarının analizi ve karşılaştırılması (Yayımlanmamış Yüksek Lisans Tezi). Marmara Üniversitesi, İstanbul.

Keskin, Y. (2009). Türkiye'de ilkokul programlarında yer alan sosyal bilgiler içerikli derslere ait öğretim programlarının gelişimine tarihsel bir bakış. Türkiye Sosyal Araştırmalar Dergisi, 13(2), 107-130. 
Keskin, Y., \& Keskin, S. Ç. (2013). İlkokul (ilköğretim) sosyal bilgiler programlarında milli bilinç ve barış değerinin tarihsel serüveni. Türkiye Sosyal Araştırmalar Dergisi, 17(3), 51-86.

Koçak, Y. (1999). Illkögretim sosyal bilgiler dersinde "milli mücadele döneminin ögretimi” (Yayımlanmamış Yüksek Lisans Tezi). Atatürk Üniversitesi, Erzurum.

Koçoğlu, E. (2012). Cumhuriyetten günümüze insan hakları ve demokrasi kavramları açısından sosyal bilgiler dersi eğitim programının incelenmesi. Dicle Üniversitesi Sosyal Bilimler Enstitüsü Dergisi, 4(7), 1-20.

Koyuncu, B. (2015). Cumhuriyetten günümüze sosyal bilgiler programlarının incelenmesi (Yayımlanmamış Yüksek Lisans Tezi). Kilis 7 Aralık Üniversitesi, Kilis.

Kozan, E. (2002). Sosyal bilgiler öğretmenlerinin sosyal bilgiler eğitimi geleneklerine yaklaşımları ve bu yaklaşımların tarih ögretimiyle ilişkisi: Ankara-Aksaray örnekleri (Yayımlanmamış Yüksek Lisans Tezi). Gazi Üniversitesi, Ankara.

Kültür Bakanlığı (1938). Ortaokul programı. İstanbul: Devlet Matbaaları

Maarif Vekâleti (1924). Illk mekteplerin müfredat programı. İstanbul: Matbaa-i Amire.

Maarif Vekâleti (1930). Ilk mektep müfredat programı. İstanbul: Devlet Matbaaları.

Maarif Vekâleti (1931). Orta mektep müfredat programı. İstanbul: Devlet Matbaaları

MEB (1948). İlkokul programı. İstanbul: Milli Eğitim Basımevi.

MEB (1949). Ortaokul programı. İstanbul: Milli Eğitim Basımevi.

MEB (1961). İlkokul programı. İstanbul: Milli Eğitim Basımevi.

MEB (1962). Ortaokul programı. İstanbul: Milli Eğitim Basımevi.

MEB (1968). Illkokul programı. İstanbul: Milli Eğitim Basımevi.

MEB (1970). Ortaokul programı. İstanbul: Milli Eğitim Basımevi.

MEB (1988). Ortaokul programı. Ankara: Milli Eğitim Basımevi.

MEB (1990). Ortaokul programı. Ankara: Milli Eğitim Basımevi.

MEB (1998). İlköğretim programı. Ankara: Milli Eğitim Yayınları.

MEB (2005). İlköğretim sosyal bilgiler dersi öğretim programı ve kılavuzu. Ankara: Milli Eğitim Yayınları.

MEB (2018). Ilköğretim sosyal bilgiler dersi öğretim programı ve kılavuzu, Ankara: Milli Eğitim Yayınları.

Merriam, S. B. (2013). Nitel araştırma desen ve uygulama için bir rehber (S. Turan, Çev.). Ankara: Nobel Akademik Yayıncılık.

Moffatt, M. P. (1957). Sosyal bilgiler öğretimi (N. Oran, Çev.). İstanbul: Maarif Basımevi.

Nalçacı, A. (2001). Cumhuriyetten günümüze ilkögrretim sosyal bilgiler programındaki değişmelerin değerlendirilmesi (Yayımlanmamış Yüksek Lisans Tezi). Atatürk Üniversitesi, Erzurum.

NCSS (Nacional Council for the Social Studies) (1993). The social studies professional. 281 Washington DC.

Özbey, S. (2001). Türkiye’de hayat bilgisi öğretim programlarının tarihsel gelişimi. (Yayımlanmamış Yüksek Lisans Tezi). Dokuz Eylül Üniversitesi, İzmir. 
Özmen, C. (2010). Sosyal bilgiler ve sını öğretmenlerinin sosyal bilgiler dersine ilişkin görüşlerinin çeşitli değişkenler açısından değerlendirilmesi (Yayımlanmamış Doktora Tezi). Gazi Üniversitesi, Ankara.

Özmen, C. (2011a). "Sosyal bilimler olarak sosyal bilgiler yaklaşımı” nın sosyal bilgiler ve sınıf öğretmenlerinin bakış açısıyla değerlendirilmesi, Uluslararası Sosyal Bilimler Eğitimi Dergisi, 1(1), 1-18.

Özmen, C. (2011b). Sosyal Bilgiler Eğitiminde Yansitıcı İnceleme Yaklaşımına İlişkin Öğretmen Görüşleri. Erciyes Üniversitesi Sosyal Bilimler Enstitüsü Dergisi, 1(30), 19-39.

Öztürk, C. (2006). Sosyal bilgiler: Toplumsal yaşama disiplinlerarası bir bakış. C. Öztürk (Ed.). Hayat bilgisi ve sosyal bilgiler öğretimi: yapılandırmacı bir yaklaşım içinde (ss. 21-50). Ankara: Pegem A Yayıncılık.

Öztürk, C., \& Dilek, D. (2005). Hayat bilgisi ve sosyal bilgiler öğretim programları, C. Öztürk ve D. Dilek (Ed.). Hayat bilgisi ve sosyal bilgiler ögrretimi içinde (ss. 4781). Ankara: Pegem A Yayıncılık.

Öztürk, C., \& Oltuoğlu, R. (2002). Sosyal bilgiler öğretiminde edebi ürünler ve yazılı materyaller. Ankara: Pegem A Yayınc1lık.

Pirinçdane, M. (1997). İlköğretim 1. kademe sosyal bilgiler ders programının değerlendirilmesi (Yayımlanmamış Yüksek Lisans Tezi). Gazi Üniversitesi, Ankara.

Safran, M. (2005). İlköğretim programlarında yeni yaklaşımlar sosyal bilgiler (4-5. sınıf). Bilim ve Aklın Aydınlı̆̆ında Ĕ̈itim, 5, 54-55.

Safran, M. (2010). Sosyal bilgiler öğretimine bakış. B. Tay ve A. Öcal (Ed.). Sosyal bilgiler ögretimi (ss. 1-18). Ankara: Pegem A Yayıncılık.

Savage, T. V. (1996). Effective teaching in elementary social studies. New Jersey: A Simon and Schuster Company.

Semenderoğlu, A., \& Gülersoy, A. E. (2005). Eski ve yeni 4-5. sınıf sosyal bilgiler öğretim programlarının değerlendirilmesi, Dokuz Eylül Buca Eğitim Fakültesi Dergisi, 18, 141-152.

Sönmez, V. (2005). Sosyal bilgiler ögrretimi ve ögretmen kllavuzu, Ankara: Anı Yayıncilik

Sözer, E. (1998). Sosyal Bilimler kapsamında sosyal bilgilerin yeri ve önemi. Can, G. (Ed.). Sosyal bilgiler öğretimi içinde (ss. 3-13). Eskişehir: Anadolu Üniversitesi Açıköğretim Fakültesi Yayınları.

Şahin, M. (2009). Cumhuriyetin kuruluşundan günümüze Türkiye'de hayat bilgisi ders programlarının gelişimi. Uluslararası Sosyal Araştırmalar Dergisi, 2(8), 402-410.

Taş, H., \& Kıroğlu, K. (2018). 2017 ilkokul sosyal bilgiler dersi öğretim programının öğretmen görüşlerine göre değerlendirilmesi. Elementary Education Online, 17(2), 697-716.

Tay, B. (2013). Sosyal bilgiler öğretiminin dünü bugünü ve yarını. R. Turan ve K. Ulusoy (Ed.). Sosyal bilgilerin temelleri içinde (ss. 5-22). Ankara: Pegem Akademi Yayıncilık. 
Tay, B. (2017). 2005 sosyal bilgiler dersi öğretim programı ile 2017 sosyal bilgiler dersi taslak öğretim programının karşılaştırması. International Journal of Eurasia Social Sciences, 8(27), 461-487.

Tuğluoğlu, F., \& Tunç, T. (2010). 1926 İlk mektep müfredatı ve cumhuriyet dönemi eğitiminin ekonomik hedefleri. Atatürk Araştırma Merkezi Dergisi, 26(76), 55-98.

Turgut, O. (1992). Cumhuriyet dönemi ilk ve ortaöğretim programlan ve bu programlardan alınan ögrenim belgelerinin değerlendirilmesi (Yayımlanmamış Yüksek Lisans Tezi). Hacettepe Üniversitesi, Ankara.

Yalnız, D. A. (2007). Cumhuriyetten günümüze ilköğretim 1. kademe sosyal bilgiler programlarının Atatürk ilkelerine göre değerlendirilmesi (Yayımlanmamış Yüksek Lisans Tezi). Adnan Menderes Üniversitesi, Aydın.

Yaman, R. (1999). Türkiye Cumhuriyetinde ilköğretim sosyal bilgiler dersi ögretiminin evrimi (Yayımlanmamış Yüksek Lisans Tezi). Yüzüncü Yı1 Üniversitesi, Van.

Yazıcı, K. (2008). 1939-1970 yılları arasında gerçekleştirilen Milli Eğitim şûralarında sosyal bilgiler ögretimiyle ilgili alınan kararlar ve uygulamaları (Yayımlanmamış Yüksek Lisans Tezi). Selçuk Üniversitesi, Konya.

Yeşil, R. (1996). Sosyal bilgiler ders programının niteliği (Yayımlanmamış Yüksek Lisans Tezi). Selçuk Üniversitesi, Konya.

Yıldırım, A. \& Şimşek, H. (2006). Sosyal bilimlerde nitel araştırma yöntemleri. Ankara: Seçkin Yayıncılık.

Yıldız, B. (2008). Çok partili dönemden günümüze sosyal bilgiler öğretim programlarındaki gelişmeler (Yayımlanmamış Yüksek Lisans Tezi). Dokuz Eylül Üniversitesi, İzmir. 